\title{
Moving toward Sustainable Rice Production in Northwest Dominican Republic
}

\author{
Derek Sindler, Pilar Useche, Catherine Tucker, Xin Zhao \\ University of Florida, Gainesville, Florida, USA \\ Email: useche@ufl.edu,derek@qcsinfo.org
}

How to cite this paper: Sindler, D. Useche, P., Tucker, C. and Zhao, X. (2018) Moving toward Sustainable Rice Production in Northwest Dominican Republic. Natural Resources, 9, 468-504. https://doi.org/10.4236/nr.2018.912029

Received: November 21, 2018 Accepted: December 26, 2018 Published: December 29, 2018

Copyright $\odot 2018$ by authors and Scientific Research Publishing Inc. This work is licensed under the Creative Commons Attribution International License (CC BY 4.0).

http://creativecommons.org/licenses/by/4.0/

(c) (i) Open Access

\begin{abstract}
Pesticide runoff from the rice production area of Las Matas de Santa Cruz in NW Dominican Republic degrades biodiversity in the ecosystems of the Yaque del Norte River, Montecristi National Park, and Caribbean Sea. This degradation prompted the Dominican NGO AgroFrontera to develop a program for the creation of a new sustainable rice value chain, starting with the formation of a rice growers association in Las Matas. This project was to evaluate "organic" as a potential certification for the new growers association. The project found that while organic certification is years away, other barriers to a sustainable rice value chain exist: competition with US rice imports due to Dominican Republic-Central American Free Trade Agreement (DR-CAFTA), an informal labor system, and access to credit. Recommendations for the new growers association include: to lower the cost of production to compete with imports, to formalize the labor system, to mediate financing for rice producers, and to maintain balanced leverage across the value chain. A recommendation for future research is the resiliency of farmer institutions against internal corruption and in-fighting.
\end{abstract}

\section{Keywords}

Rice Production, Sustainability, Organic Certification, Dominican Republic

\section{Introduction}

The purpose of this study was to determine the feasibility of, and provide an outline for, organic certification by ArroEcoZ, a rice growers association, located in the area of Las Matas de Santa Cruz, Montecristi Province, the Dominican Republic (DR). The host institution for the project was AgroFrontera, a Dominican non-governmental organization (NGO) started in 2009, which works with fishermen and farmers in Montecristi Province, located in Northwest Dominican 
Republic (NW DR), to create sustainable value chains.

AgroFrontera's program with rice producers evolved from its work with local fishermen on the coast of the Montecristi Province, around Montecristi National Park, to create a more sustainable fishing system. AgroFrontera identified pesticide runoff from the rice production area outside of Las Matas de Santa Cruz as a major negative influence on the aquatic ecosystem of the Montecristi fishing area.

AgroFrontera determined that a new program needed to be developed to create a more sustainable value chain that would encourage rice producers to use more ecologically sound practices that would be equitable for all the stakeholders in the value chain. Under the objective of a sustainable value chain, AgroFrontera developed a set of practices which reduces the need for synthetic inputs while maintaining rice yield. AgroFrontera works with over 185 rice farmers who use some of the practices.

In support of the new program, AgroFrontera has created the ArroEcoZrice growers association in the Las Matas region, with roughly 75 members. The rice production practices of the ArroEcoZ members have reduced pesticide runoff while maintaining high rice yields.

In order to create an incentive for ArroEcoZ members to maintain these sustainable practices, and for others to join ArroEcoZ, AgroFrontera has sought certification to differentiate the rice that could potentially earn a price premium within the DR.

Harvested rice needs to be processed before it is distributed to consumers, so a partner had to be found who could process and market the certified rice. Font Gamundi S.A. agreed to become that partner, and to use the certified rice for their "Arroz la Garza" premium rice brand. Font Gamundi is a Dominican conglomerate that owns production, distribution, and import/export companies of various products. The company specializes in rice, cacao and coffee exports, and imports and distributes pharmaceutical products.

The main objectives of this study were to 1 ) determine the potential for organic certification of ArroEcoZ, and 2) provide a potential roadmap for the conversion to organic certification.

Since the DR is a global leader in organic banana production, part of the project was studying how this industry grew and became established, and determining the lessons that could be useful for ArroEcoZ.

A confounding factor to AgroFrontera's plans is the Dominican Republic and Central America Free Trade Agreement (DR-CAFTA), as this agreement could have a major impact on the Dominican rice industry, including ArroEcoZ. DR-CAFTA was signed in 2006 between the United States (US), the DR, and the Central American countries, which has a provision that gradually eliminates tariffs for US rice that previously protected the Dominican rice industry from international competition [1]. In addition to addressing the main goals mentioned above, this work will summarize certain aspects of DR-CAFTA that may impact Montecristi rice producers. 


\section{Contextual Information}

\subsection{Geography and History of Dominican Republic}

The Dominican Republic shares the island of Hispaniola with Haiti and occupies the western two thirds of the island, which is west of Cuba and east of the Lesser Antilles. The DR plays a large role in the Caribbean's overall ecosystem, as they and Cuba are the largest contributors to biodiversity in the Caribbean [2]. Below is an image highlighting the DR's location [3] (Image 1).

The DR was founded as a colony of Spain which experienced various conflicts over its sovereignty between Spain, France, and the DR's neighbor Haiti, until its independence in 1844 [4]. Post-independence there were many internal conflicts within the DR, in which caudillos, or "strong men", vied for political control of the country [4]. The most notable caudillo being Rafael Trujillo, whose time in power from 1930 until his assassination in 1961 was marked by tight state control that suppressed social advancements [4].

After Trujillo, the DR had a brief period of governance by Juan Bosch in 1962 in which social reforms began, notably the Agrarian Reform. However, Bosch was pushed out and after the US military had a brief occupation of DR, Joaquin Balaguer came into power for much of the 1970's and 1980's who did not promote social reforms, such as the Agrarian Reform, and is noted for maintaining a tight grip on power [5]. In the 1990's, the Partido de la Liberación Dominicana (PLD), or Dominican Liberation Party, the political party started by Juan Bosch came into power with the election of Leonel Fernandez in 1996, and is the party of the current president, Danilo Medina [5]. From 1996 to the present has been the longest period yet for the DR in which power has transferred through non-irregular, peaceful democratic elections.

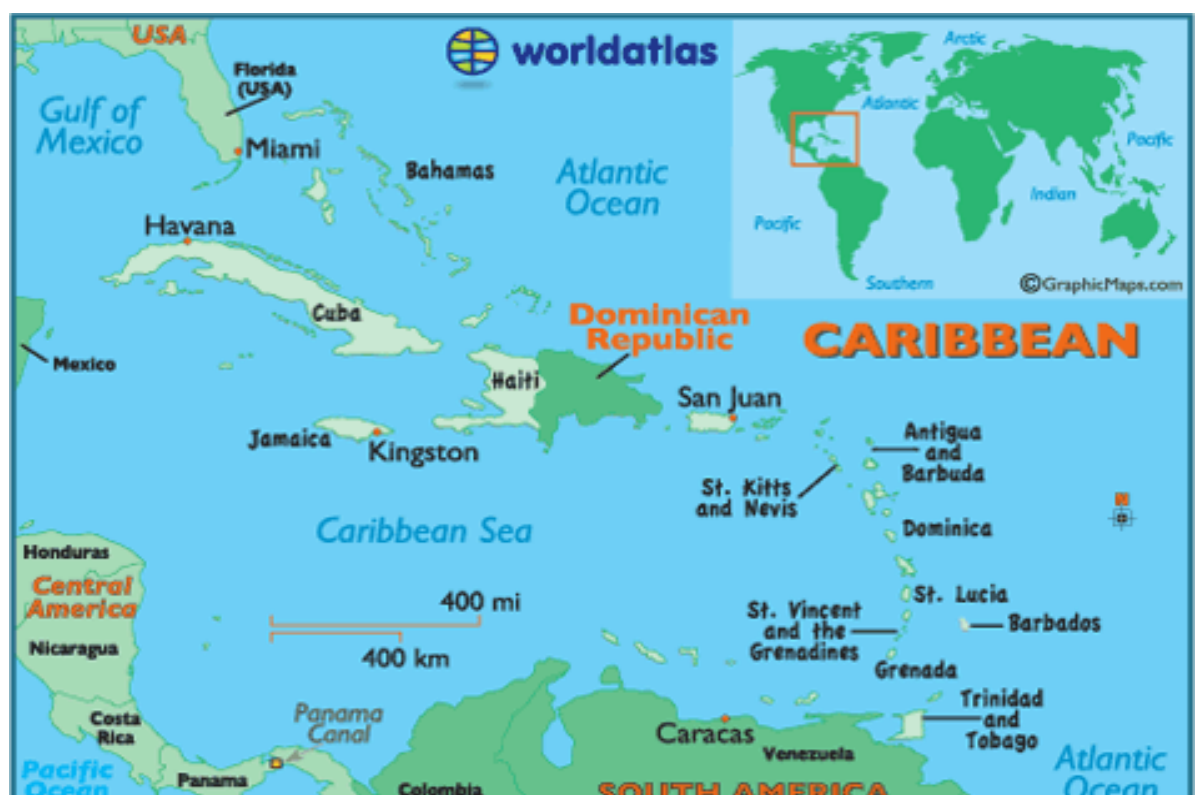

Image 1. Dominican Republic location [3]. World Atlas (2018) Dominican Republic. https://www.worldatlas.com/webimage/countrys/namerica/caribb/do.htm. 


\subsection{Economy, Health, and Education}

The Dominican Republic is an upper middle-income country which has had stable economic growth in the past three decades. The DR has averaged around 5\% economic growth between 1992 and 2014 and in the past two years, the DR has had the highest growth rates in the Western Hemisphere [6]. The GDP is mostly attributed to the service sector at $61.5 \%$, with industry accounting for $33.2 \%$ and agriculture only 5.3\% [5].

However, despite growth, poverty is still prevalent, with around $40 \%$ of the population living in poverty and around 30\% living on less than \$1.25/day [7]. The DR's scores on the Human Development Index (HDI), which is a measure national development that incorporates economic, health and education indicators, have been improving steadily (0.527 in 1980 to 0.715 in 2014) [8]. Also, DR has the $27^{\text {th }}$ highest Gini Coefficient out of 145 countries ranked [9] meaning that there is steep income inequality. Also, the Dominican economy is highly dependent on the US, which accounts for roughly half of Dominican exports, and remittances from the US equal 7\% of GDP [5]. For health indicators, life expectancy at birth is on par with its World Health Organization Region, the Americas, and World Bank Income Group, Upper Middle, at 77 years [8]. Health life expectancy (which takes into account expected years of bad health) at birth is also on par at 66 years [8]. The DR has an extensive healthcare infrastructure with 1100 primary care clinics and 200 hospitals that can provide care even to remote areas. The Dominican government spends $2.9 \%$ of GDP on health care, which is less than the average for both Upper Middle-Income Countries (3.4\%) and Latin America \& the Caribbean (3.7\%) [10].

In education, the DR lags behind in its region. According to a 2014 report by the Education Data Policy Center (EPDC) on the Latin America \& Caribbean, the DR not only scored well below its neighbors in math and reading, but the DR also has lower access to education and youth literacy rates than middle and low income countries [11]. A possible explanation is that the DR spends about half as much on education (as a \% of GDP) than other upper middle-income countries [11].

\subsection{DR-CAFTA and the Dominican Rice Industry}

The rice industry in the DR is recognized for having significant economic and social impacts on Dominican society [1]. The USDA Foreign Agriculture Service (USDA-FAS) estimates there are 30,500 producers and over 250,000 people directly involved in the rice value chain [1]. The DR has protected its rice industry from competition with foreign imports for many years, with imports coming in only to make up for differences between national production and national demand. Any rice imports mostly have come from the US. In the last several years, the DR has been mostly self-sufficient in rice production and has had minimal imports [1]. 
However, as a provision in DR-CAFTA, which was signed in 2006, protections such as import quotas and tariffs entered into a downward sliding scale, whereby protections began being reduced in 2016 and are eventually to be eliminated by 2025. Table 1 illustrates the DR-CAFTA schedule for the reduction of Dominican protections for the rice industry, and Figure 1 illustrates rice exports from the US to the DR since 2000.

Most of the literature about how DR-CAFTA will affect the DR focuses on the Dominican economy as a whole, particularly the manufacturing sector, with very little mentioning the Dominican rice industry. There have been gains by the Dominican manufacturing industry, with free trade zones, or special economic zones, benefiting the most. Special economic zones are areas within a country (such as industrial parks) that have more relaxed regulatory and tax requirements compared to the rest of the country [12]. The DR is regarded as a pioneer

Table 1. DR-CAFTA schedule of rice tariff reductions.

\begin{tabular}{ccccc}
\hline YEAR & TARIFF $\%$ & $\begin{array}{c}\text { QUOTA } \\
\text { FREE }(\mathrm{MT})\end{array}$ & $\begin{array}{c}\text { SAFEGAURD } \\
(\mathrm{MT})\end{array}$ & SAFEGAURD (\%) \\
\hline 2016 & 91.08 & 14,160 & 18,408 & 99.0 \\
2017 & 83.16 & 14,720 & 19,136 & 99 \\
2018 & 75.24 & 15,280 & 19,864 & 99 \\
2019 & 67.32 & 15,840 & 20,592 & 99 \\
2020 & 59.40 & 16,400 & 21,320 & 89.1 \\
2021 & 47.52 & 16,960 & 22,776 & 86.13 \\
2022 & 35.64 & 17,520 & 22,776 & 83.16 \\
2023 & 23.16 & 18,080 & 23,504 & 61.38 \\
2024 & 11.88 & 18,640 & 24,323 & 55.44 \\
2025 & 0.00 & 0 & 0 & 0.00 \\
\hline
\end{tabular}

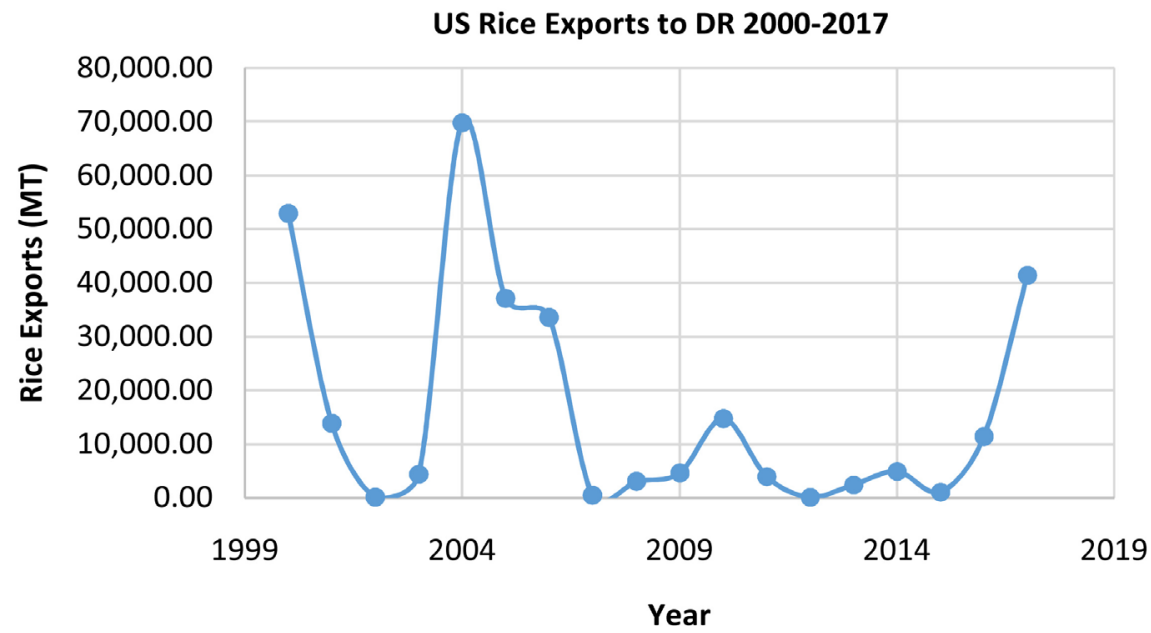

Figure 1. US rice exports to DR, 2000-2017. 
of special economic zones that fueled much of the DR economic growth in the 1990s and early 2000s, especially in the manufacturing industry [12].

The Dominican rice industry has been adversely affected by DR-CAFTA, as shown in a 2011 study by [13], which surveyed 93 farmers in the Montecristi region, and specifically named Las Matas de Santa Cruz as one of the study sites [13]. The study found that Dominican rice farmers are not competitive with US rice farmers due to private lenders being the main source of financing, and farmer associations buying few inputs or hiring machinization services [13]. The study did find that Dominican rice farmers would benefit from increased economies of scale [13]. According to an IDIAF announcement, it seems as if [13] presented the results of the study in 2010 before it was officially published, to stakeholders in the Dominican rice industry and had warned that the industry was not competitive and that many in rice farms, particularly in Montecristi would no longer be profitable after DR-CAFTA took effect [14].

However, there does not seem to be any literature on how the rice industry is now being affected after tariffs started to roll back in 2016.

\subsection{Dominican Organic Banana Industry}

The DR is the world's largest producer of certified organic bananas, accounting for 55\% of the world's production [15]. In 2015 organic banana exports were valued at US $\$ 150 \mathrm{M}$, with $95 \%$ of exports destined to the European Union (EU), and constituting about half of the EU's supply of organic bananas [15]. Production is concentrated in the northwest, in the provinces of Valverde and Montecristi. Mao, the capital city of the Valverde province, has become the de facto capital of the organic banana industry in the DR, and is the site of many different growers associations and other stakeholders in the organic banana industry. Because of the organic banana industry's established success, it was used as a benchmark to evaluate the potential of an organic rice industry in the DR.

\subsection{Agricultural Run-Off in Las Matas}

Las Matas de Santa Cruz is a city of about 25,000 in NW DR, with agriculture as the principal industry, specifically rice, banana, dairy and horticultural crops [16]. Agriculture, Fishing \& Forestry is the highest employing sector of the province [17]. The NW region accounts for about $30 \%$ of rice production in the DR, having around 40,000 hectares of rice, with the General Fernando Irrigation District in Las Matas being the principal area, with around 15,700 hectares of rice production [18]. Rice is vital to the economy of the Las Matas area, as "it is estimated that a total of 11,500 people in the area of Las Matas de Santa Cruz are directly involved in the rice production value chain" [18].

Rice production area of Las Matas is irrigated through a network of canals drawing from the Yaque del Norte River, which flows from a watershed in the central mountain range of the DR, the Cordillera Central, to the Caribbean Sea. All drainage from the rice fields flows into the Yaque del Norte as well through a 
series of drainage canals. Therefore, residues of pesticides and other agricultural inputs are carried into the river, downstream through the protected mangrove habitat of Montecristi National Park, and then into the Caribbean.

Below are two images from Google Maps to illustrate. The first, at a 1 inch $=1$ mile scale, depicts irrigation from the Yaque del Norte flowing to the Las Matas production area, and then drainage from the fields back into the Yaque del Norte (Image 2 and Image 3).

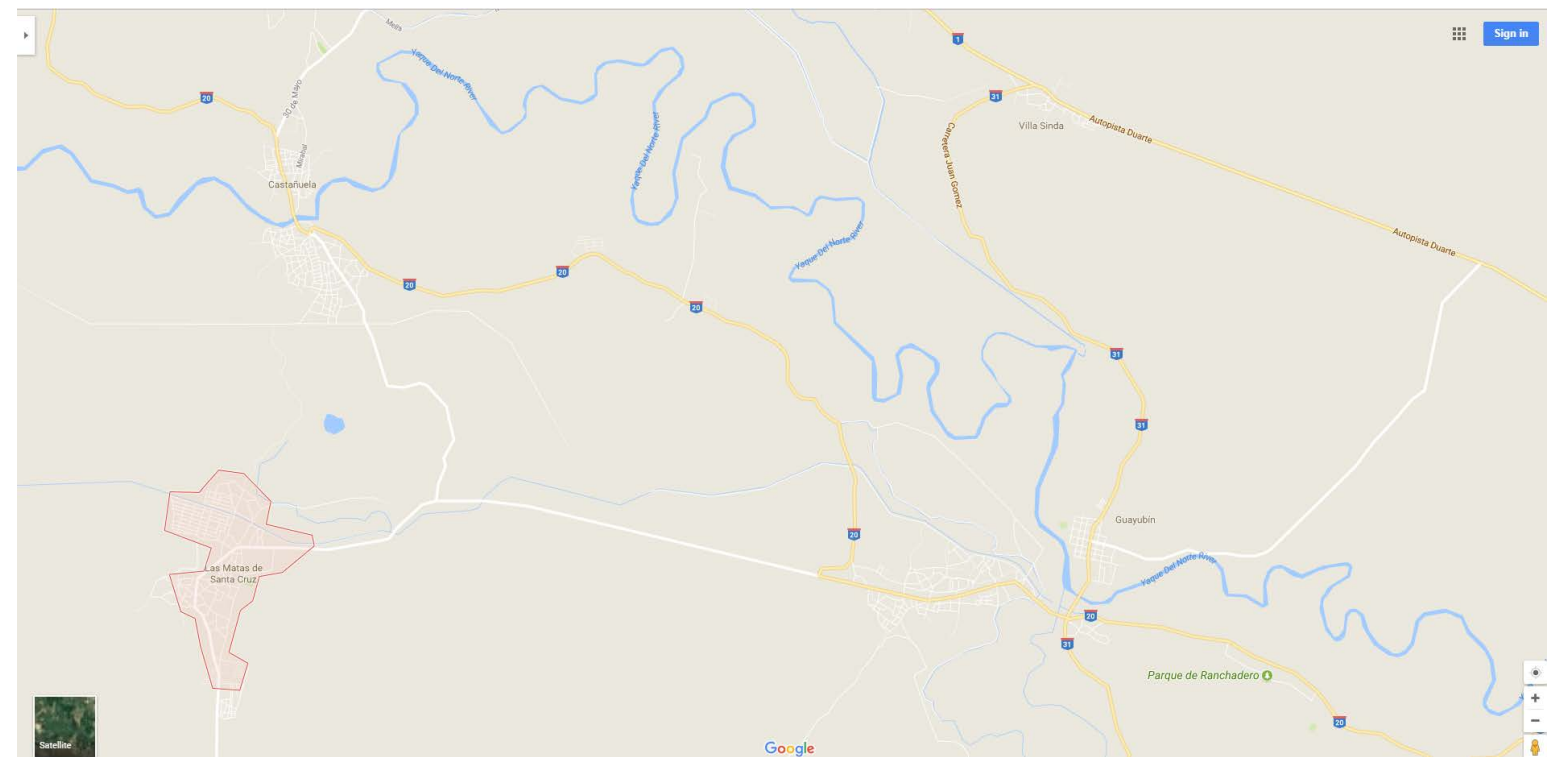

Image 2. Spatial relationship of Yaque Del Norte River to Las Matas. https://www.google.com/maps/place/Las+Matas+de+Santa+Cruz,+Dominican+Republic/@19.696595,-71.5177771,13z/ data=!4m5!3m4!1s0x8eb11440de7e7313:0xf52bb9629ca886fe!8m2!3d19.6655458!4d-71.5056249.

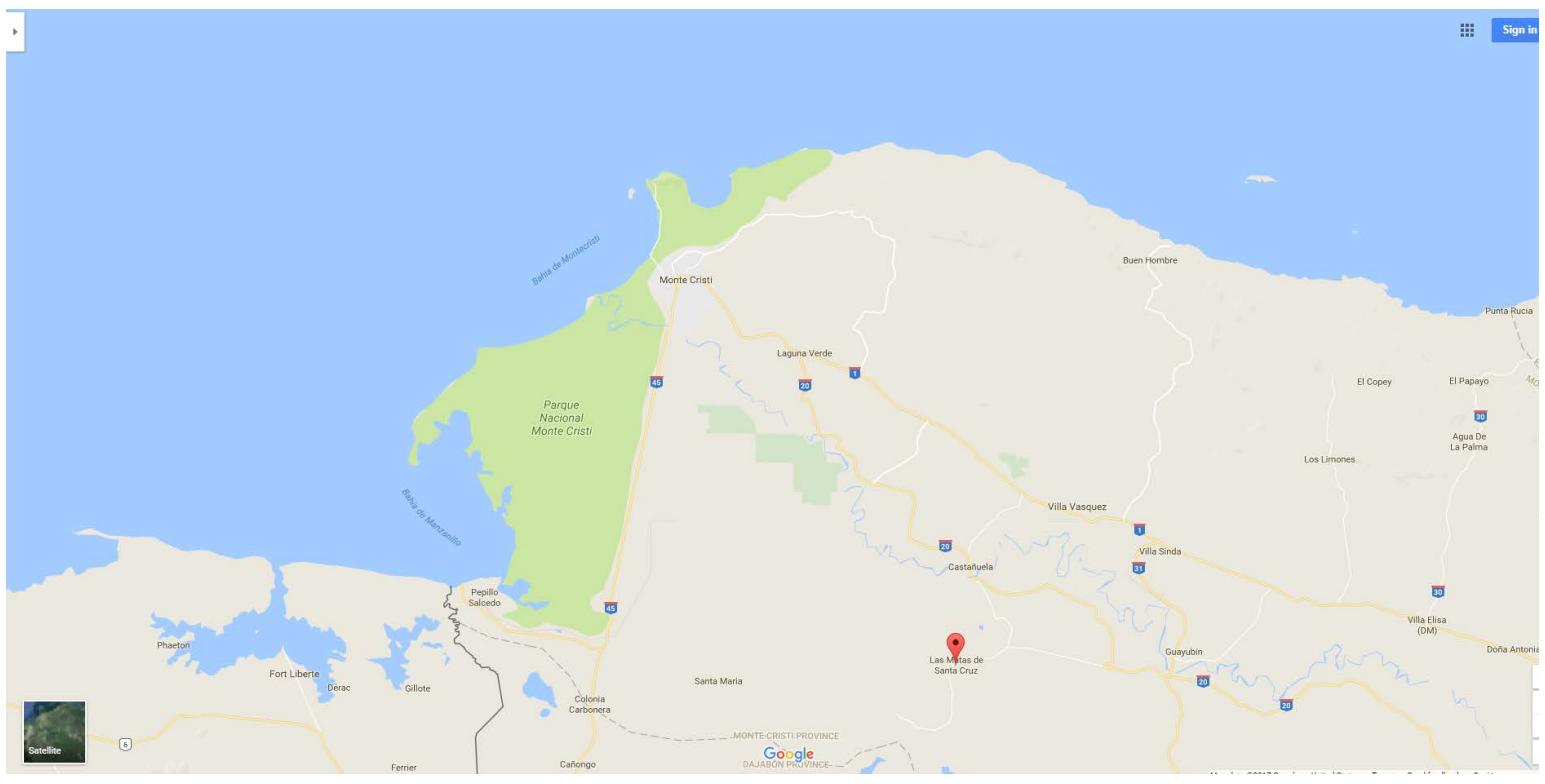

Image 3. Spatial relationship of Las Matas to Caribbean Sea.

https://www.google.com/maps/place/Las+Matas+de+Santa+Cruz,+Dominican+Republic/@19.811199,-71.5424851,11z/ data $=! 4 \mathrm{~m} 5 ! 3 \mathrm{~m} 4 ! 1 \mathrm{~s} 0 \times 8 \mathrm{eb} 11440 \mathrm{de} 7 \mathrm{e} 7313: 0 x f 52 \mathrm{bb} 9629 \mathrm{ca} 886 \mathrm{fe} ! 8 \mathrm{~m} 2 ! 3 \mathrm{~d} 19.6655458$ ! $4 \mathrm{~d}-71.5056249$. 
The second, at a 1 inch $=2$ miles scale, shows how the drainage from the rice fields into the Yaque del Norte flows through the ParqueNacional de Montecristi into the Caribbean Sea.

\subsection{Related Studies}

A report in 2016 that synthesized findings from studies of biodiversity conservation in the rice production area of southern Brazil identified four field management practices that enhance biodiversity protection [19]:

1) Keep some of the rice fields flooded during the fallow season.

2) Increase organic rice production to reduce the use of synthetic pesticides.

3) Encourage rice farmers to rejuvenate soils by taking some fields out of production.

4) Avoid draining new wetlands for rice production.

Maltchik et al. (2016) state that rewarding farmers for adopting best management practices could lead to production systems that better preserve biodiversity [19].

There was also a study done in India of rice farmers converting from conventional to organic practices. There, farmers were able to overcome fertilization and pest management challenges of organic farming by developing "green" fertilizers and pesticides, which mostly consisted of mixing cow manure with other natural ingredients [20]. Farmers also adopted System of Rice Intensification (SRI) methods at the onset of the conversion, which had an immediate positive effect on yields [20]. SRI consists of a few basic principles which are: early, quick and healthy plant establishment of seedlings (two leaf stage, usually between 8 to 12 days old at time of transplanting); reduced plant density (approximately $25 \times$ $25 \mathrm{~cm}$ grid spacing); improved soil conditions through enrichment with organic matter; and reduced and controlled water application (low water level and alternative wetting and drying) [21].

Whereas [19] and [20] indentified specific field management practices for more sustainable production of rice, this study took a more holistic approach which included social and economic perspectives to identify underlying factors in the issue of unsustainable rice production in NW DR.

As for challenges for organic farmers, especially in developing countries, a 2016 study by Jouzi et al. compiled global findings from research into organic farming, and found that the main challenges are lower yields, soil nutrient management, certification and market access, and education and research needs of small-scale farmers [22]. As for certification, the main issue is whether the price premium that organic certification brings as opposed to conventional farming can make up for yield loss and additional labor [22]. The study cites price premiums averaging $29 \%$ - $32 \%$, with yield loss estimates varying widely from $20 \%$ to $50 \%$, and additional labor costs of $7 \%-13 \%$ [22]. While this study has a similar objective to Jouzi et al. 2016 of identifying challenges and opportunities in organic farming, this study takes an in-depth look into the challenges and op- 
portunities of a particular group of farmers whose broader vision of sustainability include organic methods as a part.

In the Philippines, a farmer's cooperative called PDCI was formed to aid the conversion to organic practices [23]. One of the major challenges for PDCI was the marketing of organic rice because the marketing channels they had access to did not differentiate organic rice [23]. PDCI offered a higher price for organic rice to farmers but was unable to sell at a high enough price to make a profit [23]. Another challenge was that yields were unstable for the first few years during conversion, and some farmers became discouraged [23]. This study aims to look deeper into a value chain of sustainably produced rice to pinpoint sources of inequality and provide specific recommendations.

Also pertinent to the context of the project is the concept of Internal Control Systems (ICS) [24]. ICS is where farms within a formally organized group of farmers are randomly selected for certification inspection. If the selected farms pass certification inspection, then every farm in the organization becomes certified as well [24]. If the selected farms fail, then none of the farms will be certified. This goes for re-certification inspections as well. This method reduces certification costs since not every farm is inspected and re-inspected, but is greatly dependent on the strength of the grower association. All members must be equally committed to staying within the confines of the organic requirements. According to the International Federation of Organic Agriculture Movements [25], ICS has been used in Europe for smallholder group certification since the 1990s.

\section{Methods}

In this section, we examine the methods used during the project and introduce the different parties that were interviewed. The appendix for each instrument is the instrument's version from before the project began. There is a mix of semi-structured interviews, surveys, and one focus group.

The project was essentially split into three phases. The first phase was mainly becoming oriented to the rice production system in Las Matas.

The second phase focused on the organic banana industry to extract lessons for the rice farmers in Las Matas. During the second phase, a banana growers association in Mao, BANELINO (production classified as conventional, certified organic, Fair Trade, and biodynamic), essentially became the host organization for that phase by providing significant logistical support and allowing multiple interviews with staff.

The third phase refocused on rice in Las Matas, taking into account what was learned thus far from the contextual background through the first two phases. With a lens of looking to the future of ArroEcoZ, this phase went more in depth into particular areas of interest that had been identified. Figure 2 is a simple diagram that illustrates the logical progression of the project.

Phase 1

AgroFrontera Staff Interview (Appendix A): 


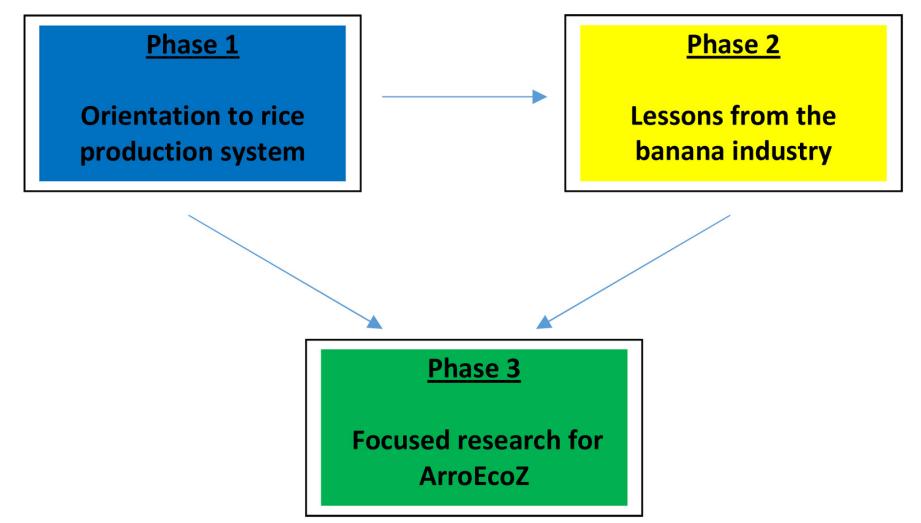

Figure 2. Illustration of three project phases.

This interview became essentially a two-week informal conversation with the staff on a daily basis. The primary information collected was basic situational awareness of rice production in Las Matas, AgroFrontera's work, and how close rice production in Las Matas was to being certified organic.

Informal Interviews with Rice Producers:

There is no appendix listed for this instrument, as these informal interviews were impromptu. For this period, the primary information collected was the value chain from the field to the mill and the challenges the producers face.

Rice Firm Interviews (Semi-structured [Appendix B]):

There were three interviews with three different firms, with AgroFrontera making the introductions. The two primary objectives were to explore the Dominican rice value chain, its potential for organic rice and any strategies to prepare for relaxing protection, and to learn how rice is processed. The first interview was with the owner of the mill who explained the milling process the rice goes through from field to final product.

The other two interviews were with financiers. Both act as intermediaries and one also sells inputs to rice producers and works for an agrochemical company.

Phase 2

Quality Certification Services (Semi-structured [Appendix C]):

Quality Certification Services (QCS) is a certifying agency in the DR, and is a subsidiary of Florida Organic Growers. QCS has an office in Mao and has had certified organic banana farms in the DR for many years. QCS provided answers about the rise of the organic banana industry in the DR, trends they see from farms going through the organic certification process, and their perspective on the Dominican organic industry as a whole.

Banana Producer Interviews (Semi-structured [Appendix D]):

Eight interviews were conducted with banana producers. All, but one, were BANELINO members, and all interviews were arranged by BANELINO. The interviews took place at each producer's farm. The primary purpose of the interviews was to identify the challenges the producers faced in their conversion to certified organic and how they overcame those challenges. 
Banana Industry Stakeholder Interviews (Semi-structured [Appendix E]):

BANAMIEL:

BANAMIEL is an organic banana growers association in NW DR, near Mao. The organization provided information on the history of the Dominican organic banana industry and BANAMIEL's role in the industry.

BANELINO (Project Officer):

The Project Officer of BANELINO was the primary contact at the organization. He provided answers about the similarities and differences between the rice and banana industries in the DR.

BANELINO (Agronomy Officer):

After the interviews with the banana producers the BANELINO agronomic technicians were interviewed next because many of the banana producers stated they simply followed BANELINO's recommendations during their organic transition.

COOPBANDO:

COOPBANDO is another growers association in Mao. The organization provided its perspective on the organic banana industry in the $D R$ and COOPBANDO's role in the industry.

Lan Fruits Company:

Lan Fruits Company is an exporter of organic bananas to Europe. The organization provided answers about growers associations in general because it had experience seeing associations from the next step in the value chain.

Phase 3

GLOBAL GAP Informal Audit (Focus Group):

This was done at the request of AgroFrontera, initially as a way of comparing AgroFrontera members to conventional growers in order to show that the growers working with AgroFrontera were better prepared for certification than conventional growers. GAP stands for "Good Agricultural Practices" and GLOBAL GAP is a certification that centers on sustainable agricultural practices and food safety. The pilot audit was to be conducted with members of the ArroEcoZ Oversight Committee, which was the committee tasked with investigating certification. However, since the answers of the Oversight Committee were representative enough of the ArroEcoZ members to obtain an overall picture of Global GAP readiness, an overall picture as opposed to a detailed assessment, was a feasible objective. The Integrated Farm Assurance Checklist, Version 5.0 was used, which is the latest version of the certification inspection checklist used by GLOBAL GAP (available at https://www.scsglobalservices.com/files/program_documents/fs-gg_cpcc_combi nablecrops_v5.0-2_july2016.pdf). The checklist covers many different types of farms, from fruit orchards, to vegetables, to grain crops. It has three categories: All Farm Base, Crops Base, and Fruit and Vegetable Base. Only the All Farm Base and the Crops Base were applicable to farms growing only grain crops, and therefore were only two categories were necessary. 
Interview with BANELINO Labor Relations Officer:

There is no appendix to reference for this semi-structured interview. The interview was scheduled after the GLOBAL GAP Informal Audit, in response to the weakness of the "Health, Safety, and Wellbeing of the Workers" section (more information on the results of the GLOBAL GAP Informal Audit is in the RESULTS section). To understand how BANELINO addressed this issue, and how they managed farm labor, the BANELINO Labor Relations Officer was interviewed.

Price Comparison of US v. Dominican Rice (Secondary Data Analysis):

It was necessary to explore the possible effects of DR-CAFTA, specifically the relaxation of protective tariffs for the Dominican rice industry. AgroFrontera staff and producers knew the Dominican rice industry would be affected, but there had not yet been a formal analysis. The DR-CAFTA sections pertaining to rice, as well as data on rice exports to the DR from the USDA-FAS Global Agricultural Trade System (GATS) were provided by the USDA-FAS office at the US Embassy in Santo Domingo.

Analysis of Secondary Data from Rice Harvest:

Data was collected by AgroFrontera from ArroEcoZ members for the June 2017 harvest in order to find the relationships of certain variables with farm profitability. AgroFrontera regularly collects data from farmers that includes farm size, yield, inputs (fertilizers, herbicides, insecticides, and more), labor, and other key measurements. Farm size is in terms of "tarea", which is 628 square meters and is a common measurement of land in the DR in order to control for farm size.

Debt Survey (Appendix F):

The Debt Survey was developed while in the field, during the last few weeks of the practicum. The survey was created because there appeared to be a conflict with the conditions placed on loans from agrochemical companies that producers and AgroFrontera staff talked about, and the operational plans of ArroEcoZ. The purpose of the survey was to determine how many ArroEcoZmembers borrow from agrochemical companies, and to find out more about the conditions. The survey was administered to participants at one of the ArroEcoZ general meetings, with 50 producers taking the survey.

\section{Results}

The Results section is primarily split into two categories: Certification for ArroEcoZ and Viability of Rice in NW DR. While there is a substantial number of individual findings from the project, these two categories were the main themes.

Certification for ArroEcoZ

It was found early on in the project that organic certification is not a realistic option for the near future. Table 2 illustrates a representative sample of substances prohibited in organic production currently used by ArroEcoZ members, indicating that prohibited substances are still being relied upon. 
Table 2. Inputs used by ArroEcoZ members.

\begin{tabular}{|c|c|c|}
\hline Input & Use & Quantity used \\
\hline Triumph & $\begin{array}{c}\text { Herbicide used for grasses, } \\
\text { broadleaf and narrow-leaf weeds }\end{array}$ & $0.15 \mathrm{~L} /$ tarea (1 application) \\
\hline Balanced Fertilizer & $\begin{array}{l}\text { Various formulas of the three } \\
\text { essential elements }\end{array}$ & $0.9 \mathrm{~K} /$ tarea (1 application) \\
\hline $\begin{array}{l}\text { Nitrogen Fertilizers } \\
\text { (Ammonium Sulfate) }\end{array}$ & $\begin{array}{l}\text { Added nitrogen for use just } \\
\text { before grains form }\end{array}$ & $0.2 \mathrm{~K} /$ tarea (1 application) \\
\hline Uhmi-Arroz & Foliate & $0.06 \mathrm{~L} /$ tarea (1 application) \\
\hline Agrosol & Growth hormone & $0.06 \mathrm{~L} /$ tarea $(1$ application $)$ \\
\hline Cipemetria & $\begin{array}{l}\text { Spodoptera (armyworm) } \\
\text { control-kills larvae }\end{array}$ & $\begin{array}{l}0.016 \mathrm{~L} / \text { tarea (between } \\
2 \text { applications) }\end{array}$ \\
\hline Imidacloprid & $\begin{array}{l}\text { Sogata, Whiteflies, } \\
\text { Hydrelia moths }\end{array}$ & $\begin{array}{c}0.023 \mathrm{~L} / \text { tarea (between } 3 \\
\text { applications) }\end{array}$ \\
\hline Muralla & $\begin{array}{l}\text { Sogata, Whiteflies, Hydrelia } \\
\text { moths (effective against larvae) }\end{array}$ & $\begin{array}{l}0.0078 \mathrm{~L} / \text { tarea (1 application in } \\
\text { rotation with Imidacloprid) }\end{array}$ \\
\hline Mancozeb & Fungicide & $0.06 \mathrm{~K} /$ tarea ( 1 application) \\
\hline Kasumin & Bactericide & $0.04 \mathrm{~L} /$ tarea (1 application) \\
\hline Carbendazim & Fungicide & $0.04 \mathrm{~L} /$ tarea $(1$ application $)$ \\
\hline Surfacid & $\mathrm{pH}$ regulator & $\begin{array}{c}0.023 \mathrm{~L} / \text { tarea (between } 3 \\
\text { applications) }\end{array}$ \\
\hline
\end{tabular}

In speaking early on with AgroFrontera staff, the leadership expressed the desire to pursue organic certification and viewed production without any use of synthetic inputs as sort of an "end state". However, AgroFrontera and ArroEcoZ were looking to differentiate their rice sooner rather than later, utilizing the current set of conservation practices (Table 3).

A key finding was that AgroFrontera has experimented with SRI methods, which they recommend but do not make mandatory in their set of practices because SRI methods were determined to be economically infeasible for the Las Matas producers due to the additional labor necessary to transplant versus direct sowing. There has been the suggestion of purchasing small-scale transplanters that would decrease the labor required for planting.

Additionally, none of the rice firms interviewed in Phase 1 expressed any interest in organic rice. The most positive outlook for organic Dominican rice was "possibly". Once it became clear that the timeline for organic conversion was years into the future, the project's scope broadened past strictly looking at organic certification.

\subsection{Lessons from the Organic Banana Industry}

The genesis of this substantial industry was essentially linking a production system that was already close to certified organic with an already existing market in Europe. The DR organic banana industry originated in the southwest province of Azua in the mid 1980s. The market for conventional bananas in the DR was 
Table 3. AgroFrontera's conservation practices.

1. Plating times are December $20^{\text {th }}-$ Jan $31^{\text {st }}$ and June $25^{\text {th }}-$ August $5^{\text {th }}$

2. Crop residues are incorporated into the soil instead of burning.

3. Fields are flooded before preparing for a new planting to eliminate weeds and volunteer rice plants (plants coming up from leftover seeds in the field from previous season).

4. There is a barrier, planted with cover (grass), between the parcel and main drainage collection points.

5. Barrier mounds on the outside of the parcel are planted with cover (grass).

6. Internal drains are planted with cover (grass).

7. There is a system to maximize water efficiency.

8. The design and construction of boundaries and curves within the parcel are level.

9. After leveling and bringing in water, leave 24 hours before draining the fields to plant.

Plant Density: For direct sowing, $10 \mathrm{lbs} /$ tarea of seed should be used, not $18-20$

10. $\mathrm{lbs} /$ tarea. Transplants should be planted at $15-18$ days old, with $2-3$ transplants in a group, spaced at $30 \mathrm{~cm} \times 30 \mathrm{~cm}$.

Integrated Weed Management: After preparing the land, flood the field to $2 \mathrm{~cm}$ high of water and wait at least 24 hours before draining to kill weed seeds and volunteer rice

11. plants, so there will be a clean surface when planting, and soil particles can settle before the water is drained. It is recommended to minimize the use of chemicals, and control weeds mechanically and/or manually.

Integrated Pest Management: Dig a hole one square meter by one meter deep in the

12. parcel's main irrigation canal, where the irrigation enters the field, which will act as a trap for aquatic snails that attack growing rice plants.

Integrated Fertility Management: Incorporate crop residue into the soil after each harvest. Get a soil test and with its recommendation(s), make a fertilization plan for the entire season. AgroFrontera recommends (and is considering to make this mandatory) planting a cover crop (perennial peanut, Arachisglabrata, which fixes nitrogen) once a year, after two consecutive rice harvests, and incorporating the plants into the soil for green manure.

Integrated Water Management: Give intermittent irrigation in the crop development

14. stage (2 months), from planting to grain formation, with water $2-4 \mathrm{~cm}$ high. Until rice matures, maintain water at $8-10 \mathrm{~cm}$ high.

volatile, with many major buyers, such as Chiquita, leaving and forcing Dominican producers to sell locally for much lower prices, which meant lower revenues for buying conventional inputs. The Dominican producers adapted and developed practices that compensated for the low use of inputs. The drier climate of western DR is also significant, as this helps to reduce disease pressure, especially from Black Sigatoka, a fungal disease that has a major impact on banana production. Another factor in reducing disease and pest pressure without inputs was that production was spread out among small plots, with different agricultural activities such as dairy, rice, and horticultural crops in between. This sort of spread out production created a system reflective of crop rotation, which is a component of integrated pest management and is required for organic certification. 
The idea of exporting organic bananas to Europe took hold as the demand for organic products in Europe steadily increased in the 1990s. The industry started with a few shipments to Europe and grew exponentially from there, eventually moving from the AzuaProvince to the Valverde Province because of better access to irrigation.

The role of growers associations during the rapid growth of the industry was evident from the interviews in Phase 2. BANELINO's Project Officer stated that the number of associations multiplied 3 - 4 times during the "boom". Not every association became successful, however, as some had issues with corruption in leadership. Where there was honest leadership, associations succeeded; and where leadership was corrupt, which often meant stealing funds from the association, the associations failed. According to BANELINO's Project Officer, even with a successful association such as BANELINO, a tradeoff exists between the egalitarian (horizontal) style of management of a collection of independent growers and the vertical (command and control) style of management of large, corporate style farms. In growers associations, the farmers retain independence, earning their own incomes and having a voice; however, logistics become much more complex and less efficient with the horizontal style of management than with the vertical style of management.

As for technical assistance from associations, BANELINO found that soil organic matter and bio-ferments (an agricultural input made from mixing locally produced effective microorganisms with soil and allowing it to ferment to increase the microbial population, and then mixing the ferment with water to create an input that can be sprayed to increase the soil's biological activity) are key. All eight of the banana producers interviewed said they followed the technical advice from their association's agronomists, and none had major difficulties with their transition. Several mentioned the importance of adding soil organic matter. QCS stated the inputs for pest and disease management were noted as the most difficult inputs for producers to give up, and residues from past use often was the reason for farms failing the certification inspection.

Similar to how the production system was refined by agronomists to ensure meeting organic requirements by the banana industry, AgroFrontera did discuss the possibility of writing a grant to rent land for a test plot in order to develop a fully organic production system.

\subsection{GLOBAL GAP Informal Audit Results}

The request from AgroFrontera to investigate ArroEcoZ members' readiness to meet GLOBAL GAP requirements was based on the logic that GLOBAL GAP requires sustainable (but not strictly organic) production practices, for which ArroEcoZ members would be more suited. While the exercise did not meet its initial intended objective of comparing ArroEcoZ growers to conventional growers, it did reveal the potential strengths and weaknesses of ArroEcoZ as an institution, and identified areas for the association to focus on. 
Of the GLOBAL GAP Integrated Farm Assurance Checklist, Version 5.0, All Farm Base and Crops Base categories, 50 control points (GLOBAL GAP term for the requirements specified by the checklist)were marked as "Yes", 47 control points were marked as "No", and 18 control points and 4 sections were marked as "N/A". In addition, 5 control points and 4 sections were not scored.

The sections of the checklist in which producers had the best scores were "Soil Management and Conservation", "Fertilizer Application", "Integrated Pest Management, Plant Protection Materials", "Waste and Pollution Management", and "Conservation and Plant Propagation Materials". These sections of the checklist were more technical in nature and dealt with the production side of farming. This area overlapped the AgroFrontera's conservation practices, so it was not surprising to see that ArroEcoZ members scored well on these sections.

The areas in which producers scored the lowest were "Health, Safety, and Wellbeing of Workers", "Hygiene, Record Maintenance/Internal Inspection", "Traceability, Food Defense", and "Mass Balance".

The "Health, Safety, and Wellbeing of Workers" section would be the most difficult area of GLOBAL GAP readiness to overcome because the labor system in the rice industry in Las Matas is entirely informal. Rice producers pay Haitian laborers per job (i.e., land leveling, spraying, harvesting, etc.) without any type of formal contract. Producers may have one regular worker who adjusts the irrigation borders, but there is not a formal employment arrangement. The gulf between the checklist (which requires workers to be legally authorized to work; safety training of workers to be documented; and much more formalization of labor) and the reality on the ground is wide.

With this challenge of the labor system in mind, an interview was conducted with BANELINO's Labor Relations Officer for laborer commendations in accordance with GLOBAL GAP requirements and requirements of other certifications. BANELINO recommended that ArroEcoZ identify an adequate labor pool to support all its members. Legal status is critical (as almost all agricultural labor in DR is from Haitian immigrants) because each worker in the labor pool must be registered with the Dominican government and legally authorized to work in the DR. All workers in the labor pool will need to be registered for Dominican social security, healthcare and workman's compensation, and formal payroll records must be kept. This type of setup would essentially require ArroEcoZ to act as a temporary employment agency, and be able to manage employment records. There is the choice of having ArroEcoZ managing workers' schedules, assigning them to producers as needed, or having workers be permanently assigned to producers.

The other sections where ArroEcoZ scored poorly are more administrative in nature and mostly require good recordkeeping and having written procedures. ArroEcoZ is still deficient in these areas, but these problems are easier to overcome than the challenges in the labor system. QCS also identified documentation as a problem area. In the organic banana industry, growers associations are 
able to assist small plot members with this task, again underscoring the importance of associations for small farmer certification. For ArroEcoZ to build its institutional capacity in the area, it was found that it is possible to hire a GLOBAL GAP "Farm Assurer" (i.e., someone who is authorized by GAP to be hired by organizations to help them prepare for certification).

\subsection{Viability of the Rice Industry in NW DR}

After it was established that organic certification was not an immediate priority, the project adjusted focus on the viability of the rice industry in Las Matas, in particular for ArroEcoZ.

Price Comparison of US v. Dominican Rice:

There was concern among the DR rice producers, rice firms, and AgroFrontera staff that DR-CAFTA would have a significant impact on the industry; however, reports or documents that gave any specific outlook could not be found. Therefore a simple comparison was done, first comparing current prices of US rice exported to the DR v. Dominican rice, and then the tariff reduction schedule was referenced.

According to [26], the US exported a total of 39,852 metric tonnes (MT), which is 2204 pounds, of rice at a total value of US\$20,145,000 from January 2017 to April 2017 [26]. This comes to an average price among all products of US $\$ 505 / M T$. From this total, $99.5 \%$ was milled rice ready for consumption, with 14,401.2 MT of parboiled (partially cooked) rice at US\$522/MT. Milled long grain rice constituted 25,277 MT at a price of US $\$ 493.51 / \mathrm{MT}$, and is what would be in direct competition with Dominican rice. The price calculated for processed white rice in the DR, using the price quoted by the mill that was interviewed, is US\$767/MT $(\mathrm{RD} \$ 2050 / 125 \mathrm{lb}$ sack $/ 125=\mathrm{RD} \$ 16.4 / \mathrm{lb} \times 2204 \mathrm{lbs}=\mathrm{RD} \$ 36$, $145 / \mathrm{MT} / 47.1 \mathrm{RD} / \mathrm{USD}=\mathrm{USD} \$ 767 / \mathrm{MT})$. At the time of the project, the exchange rate was US $\$ 1=\mathrm{RD} \$ 47.1$. In 2017, most of the imported rice (tariff-free quota was $14,160 \mathrm{MT}$ ) faced an $83 \%$ tariff rate, which pushed the price of milled long grain rice to US\$903.12/MT.

At $\$ 767 / \mathrm{MT}$, Dominican rice is $55 \%$ higher than US rice before tariffs, therefore a $55 \%$ tariff rate makes the prices even, and tariff rates below $55 \%$ make US rice cheaper. Also, quotes for tariff-free MT are rising, so more rice will come in without any tariff being applied. Tariffs will drop below 50\% in 2021,as highlighted in Table 4, meaning that if the gap between US and Dominican rice remains steady, imported US rice will be cheaper than Dominican rice in 2021 no matter that tariffs are still in place. This means DR-CAFTA will begin seriously affecting the Dominican rice industry in 2021. Table 4 illustrates the decrease in protections according to DR-CAFTA. Note that in 2021 the tariff rate drops below $50 \%$.

\subsection{Production System and Challenges for Producers in Las Matas}

In order to understand the price differential between US and Dominican rice, it 
Table 4. DR-CAFTA schedule of rice tariff reductions.

\begin{tabular}{ccccc}
\hline YEAR & TARIFF $\%$ & $\begin{array}{c}\text { QUOTA } \\
\text { FREE }(\text { MT })\end{array}$ & $\begin{array}{c}\text { SAFEGAURD } \\
(\text { MT })\end{array}$ & SAFEGAURD (\%) \\
\hline 2016 & 91.08 & 14,160 & 18,408 & 99.0 \\
2017 & 83.16 & 14,720 & 19,136 & 99 \\
2018 & 75.24 & 15,280 & 19,864 & 99 \\
2019 & 67.32 & 15,840 & 20,592 & 99 \\
2020 & 59.40 & 16,400 & 21,320 & 89.1 \\
2021 & 47.52 & 16,960 & 22,776 & 86.13 \\
2022 & 35.64 & 17,520 & 22,776 & 83.16 \\
2023 & 23.16 & 18,080 & 23,504 & 61.38 \\
2024 & 11.88 & 18,640 & 24,323 & 55.44 \\
2025 & 0.00 & 0 & 0 & 0.00 \\
\hline
\end{tabular}

is important to know the production system in the DR and the challenges that Dominican producers face. This description of the production system in Las Matas is mostly from the point of view of the producers and largely involves the role of financing. The use of private financing was identified as a factor in making the rice industry in NW DR nonviable in [13], and it was important to followup on this subject.

1) Interlinked financing, input supply, harvest, and post-harvest services

When using BancoAgrícola (a Dominican state bank for the agriculture industry), a cooperative, or self-financing (primarily remittances from family in the US), the producer receives an amount upfront and then pays cash for inputs, machinery, and manual labor. Private financing (a source other than BancoAgrícola, a cooperative, or self-financing) generally lends inputs, which are noted on an account for the producer and may also lend cash to pay for machinery and labor. Other private financers have machinery teams that provide services such as tilling and land-leveling that are also charged to a producer's account in addition to inputs. Manual labor is always financed with cash loans, as opposed to being charged to a producer's account, regardless of the financing source.

The rice harvest is seen as the collateral for the money and capital loaned during the season, thus, when the rice is harvested, those that used private financers have the rice hauled to the mill by the financers. The financer pays for trucks to haul the rice to the mills. The mill pays the financer; the financer keeps what is owed by the producer and then sends what is left to the producer. Even those who used non-private financing (i.e., BancoAgrícola or a cooperative) often still use financers as intermediaries to haul rice from the field to the mill because producers do not have trucks for transporting the rice and the intermediaries do.

2) Prices for Inputs 
Every producer stated that there are two different sets of prices for inputs and machinery: a lower set when the producer has cash to pay immediately, and a higher set of prices when inputs and machinery are privately financed and noted in the producer's account. The producer is also charged a $15 \%$ interest rate on top of the higher price that is charged to the account. It appears that $15 \%$ is the standard interest rate charged by all private financers and is applied to everything that is loaned to producers, whereas non-private financers like BancoAgrícola and cooperatives charge $8 \%-12 \%$.

3) Technical Assistance

Most technical assistance to the producers is provided by Dominican state agronomists, apart from financing. BancoAgrícola does send out agronomists to those who borrow from them, but it is more to verify certain steps of production rather than provide technical assistance.

4) Product prices

According to all of the rice firms interviewed, prices for unprocessed rice are usually set by mills before harvests through mill association meetings; however, become flexible as some mills acquire volume faster and then other mills offer higher prices to then catch up. Both of the private financers interviewed stated they negotiate prices with mills, and one named a price range, with a US $\$ 0.53 /$ fanega (a 100 kilogram sack) difference between high and low. Non-privately financed producers have the ability to bargain directly with mills themselves for the best price available because their harvest is not "owed" as the guarantee for loans; in which case, the mill sends trucks to bring the rice to the mill. The producer is then paid by the mill after processing. Other non-privately financed producers still look for a private financer to be an intermediary to buy the rice from the producer and then negotiate with the mills, in which the financer takes the rice to the mill, is paid by the mill, and then pays the producer. It is common for financers to offer to provide logistical services between the field and the mill for free in exchange for the producer buying inputs from that financer for the next season.

\section{5) Rice Distribution}

From the mill, rice has two principal methods for distribution to consumers. One method of distribution is for premium rice, which is sold in prepackaged bags of $1,2,3$, and 5 pound bags in supermarkets that have distinct brands, mainly from three major companies (Font Gamundi, Pimco, and Bisano). These companies both buy white rice from mills and have their own mills. At the processing site, rice is sifted to retain unbroken grains that are packaged by the companies and then distributed to supermarkets. This is the method that Arro$z E c o Z$, along with AgroFrontera, use to sell "sustainable rice" (high quality rice). The other method of distribution is for regular rice, which is distributed to retail outlets in bulk sacks, containing broken and unbroken grains. Consumers buy regular rice by weight at the outlet.

As for marketing strategies by rice firms, the mills use "open sales" to market white rice, meaning all sales are transactional without contractual arrangements. 
The financers bid their rice to mills on a transactional arrangement as well.

6) Traps

Nearly every producer interviewed stated that the private finance firms set traps as follows:

a) Higher prices for inputs and machinery when using financers, as opposed to cash.

b) Discounts for impurities, which are determined by mills based on how much material other than sellable rice is in the bulk amount received from the field (includes husks, stalks, and broken grains). Discounts often come in two stages. During the first discount stage, financers (acting as the intermediaries between them and mills) come to the fields around harvest time to offer the discount they will charge for the harvest based on how the field looks (the better the field looks, the less broken grains there will be, and the lower the discount). During the second discount stage, financers charge a higher discount than they originally set after the rice is milled. The farmers have no recourse nor any power to negotiate discounts.

c) Producers taking on too much debt for things other than rice production. BancoAgrícola and the cooperatives lend money only for rice production activities, which has to be verified by the bank, whereas private financers do not have such requirements and will lend cash for the producer to spend unrestrictedly.

\section{7) Fractionalization}

In this case, the producers are not organized into associations, and many are smallholders (around 4 hectares), which leads to no real economies of scale nor negotiating power. Production activities, especially those which involve machinery, are more expensive because producers pay only for their own parcels.

\section{8) History/Land Tenure}

The current issues of producers being unorganized and not having access to credit is tied into the history of the Agrarian Reform in the DR. The following is an account based on multiple conversations with producers and AgroFrontera staff:

Land in the DR is predominately owned by a small number of powerful families, with land in NW DR belonging to just a few families since colonization. In 1962, President Juan Bosch began the Agrarian Reform. Land was redistributed to farmer associations (colectivos), which were given provisional titles in the 1960s. Individual producers did not receive provisional titles until the 1980s. After years of continued solvent production, producers became eligible to obtain a definitive title, which has greater rights associated with it. There were problems in the earlier years of the Agrarian Reform where loan preferences were given to the larger producers. Eventually, many small producers lost faith in BancoAgrícola and went with private financers.

\subsection{Debt Survey Results}

Before going into the results, there needs to be an explanation of what informa- 
tion the survey sought and why that information was important. Private financing was identified as a factor driving up the cost of production, so there was the need to quantify how many ArroEcoZ members use private financing. Also, private financers did not allow borrowers to market their rice themselves, which impeded ArroEcoZ from marketing its members' rice to companies such as Font Gamundi. There were the questions of whether lenders would loan cash for producers to buy their own inputs or only supply inputs on credit, and whether producers' sources of financing allowed them to shop around for inputs. These conditions seemed to be mechanisms that drove up the cost of production. It was determined that inputs were sold for lower prices when producers paid for them in cash, and ArroEcoZ was limited in developing bulk purchasing programs to lower the cost of production. AgroFrontera was well aware of these conditions.

Since AgroFrontera was well aware of the issue of private financing, part of the reason for establishing ArroEcoZ was for the association to have a credit program for producers. The program was designed for ArroEcoZ to take out a bulk, or institutional loan, and then with a Credit Committee divide the funds into smaller loans for individual producers. Producers would then pay back ArroEcoZ who would then make payments back to the original lender. One important note here is that BANELINO facilitates member finances differently by being a cosigner for loans from a financial institution.

A potential barrier to ArroEcoZ's credit program would be yet another loan condition. If a producer has any outstanding or residual debt with a private financer after a season is finished, the producer must settle that debt before moving to an alternative source of financing. If the producer chooses with an alternative source of financing the next season without settling the debt first, the financer can take the title to the producer's land. It was therefore important to find out how many ArroEcoZ members had outstanding debts to know if there was a substantial amount of members who could not join a new credit program.

An explanation of the different types of sources in Figure 3 is as follows:

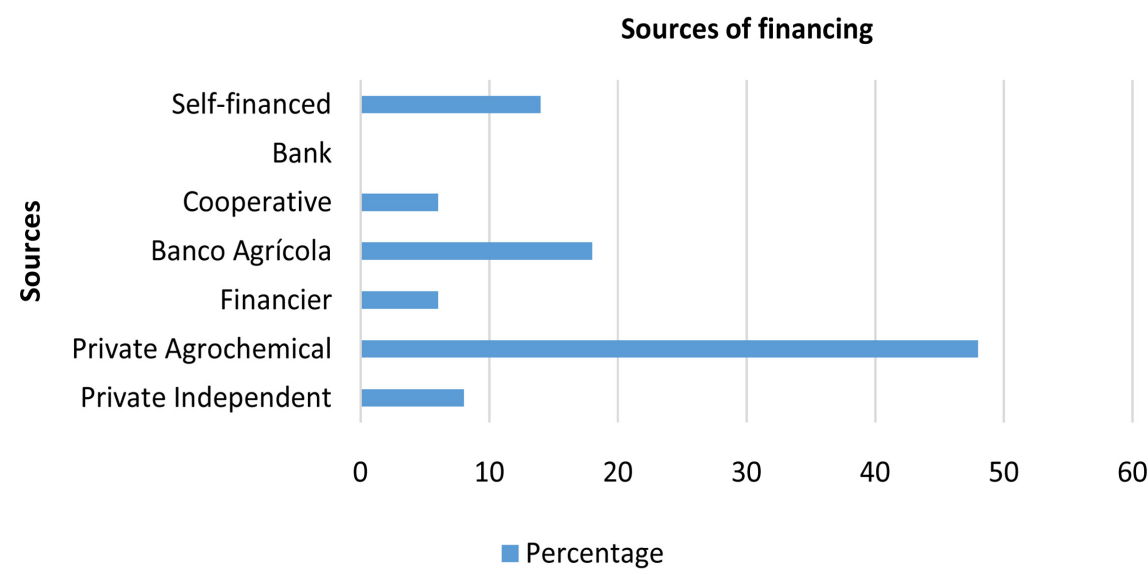

Figure 3. Sources of financing for ArroEcoZ members. 
- Self-financed: Producer using own money to finance the season. Just from talking to producers, it seemed this was mostly due to remittances from family in the US.

- Bank: A typical private bank. Banks do not lend to rice farmers due to strict qualifications for loans that most producers do not meet.

- Cooperative: Essentially credit unions with average interest on loans of $8 \%$ $12 \%$.

- BancoAgrícola: The Dominican state bank for the agricultural sector, with average interest on loans of $8 \%-12 \%$.

- Financier: A private lender that only provides financing and does not sell inputs, with average interest on loans of $15 \%$.

- Private Agrochemical: An input supplier tied to a major agrochemical company that also provides financing, with average interest on loans of $15 \%$.

Private Independent: An input supplier not tied to an agrochemical company that also provides financing, with an average interest on loans of $15 \%$.

As shown in Figure 3, private agrochemical financing is the most common source for ArroEcoZ members. In total, between Financier, Private Agrochemical, and Private Independent, $62 \%$ of ArroEcoZ members use financing that charges higher interest rates.

Figure 4 illustrates the percentage of ArroEcoZ members that reported their source of financing places conditions on loans, such as not lending cash to producers to purchase inputs, not allowing producers to search for inputs themselves, and not allowing the producers to market their rice themselves. For each condition, the bar to the left is the percentage of the members surveyed that reported experiencing these conditions. The bar to the right is the percentage of only those that use Private Agrochemical as their source of financing.

As shown, a high portion of the total population of ArroEcoZ members are constrained by conditions from their source of financing. About $50 \%$ of the ArroEcoZ members are paying a higher credit price for inputs, 50\% are not allowed

\section{Loan Conditions}

\section{0}

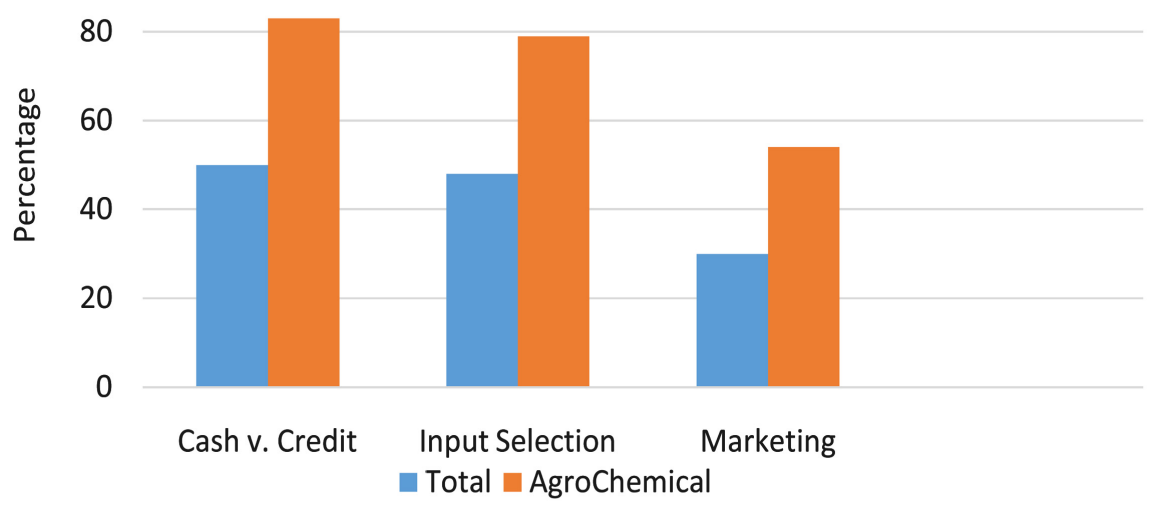

Figure 4. Conditions on agricultural loans per ArroEcoZ members. 
to participate in bulk purchasing programs which also significantly diminish the ability of ArroEcoZ to lower the cost of production, and 30\% are limited in marketing their rice to Font Gamundi. This means that alternative financing is necessary before ArroEcoZ can have a viable agreement with Font Gamundi.

With roughly half of the members using Private AgroChemical as their source, it is important to look at this subpopulation in particular. The rate of conditions is significantly higher than for the total population, with most placing conditions on cash and input selection. Conversely, BancoAgrícola and cooperatives do not (and obviously not self-financed) place such conditions on financing.

Only three members reported that they have outstanding debt (US $\$ 14,862$; $\$ 10,616 ; \$ 16,985)$, meaning all but those three would be able to switch sources of financing once an alternative source became available. All reported that their land's title is being used as the guarantee for loan repayments. Debt issues could be a major barrier for future recruitment of other rice producers into the association. If producers are limited to private financing due to outstanding debt, and especially if they cannot market their own rice, they will essentially be prevented from joining ArroEcoZ, or at least unable to market differentiated rice to Font Gamundi.

\subsection{Analysis of Secondary Data from June 2017 Harvest}

For the following analysis, the "Costos Conservacion" ("Conservation Costs") data were collected by AgroFrontera. Farm size is in tareas, yield is in fanegas, dollar amounts are US dollars (converted from Dominican pesos, which was the currency used when AgroFrontera collected the data).

Originally, the intent of the analysis was to understand the profit structure of ArroEcoZ members as part of estimating the potential impacts of organic certification on profitability. However, the exercise revealed, the potential for analytics, especially in looking at the more information was realized, such as the relationship between variables (inputs, yield, labor) and profitability. The following analysis is only a glimpse what could be discovered with an in-depth analysis.

\subsection{Farm Size}

Figure 5 illustrates the size of the farms in the dataset. Most farms are relatively small, being under 66 tare as (i.e., 4.125 hectares, or about 10 acres), which reinforces the fractionalization challenge that producers claimed.

There was the question of the size of the farms in the dataset. As one can see, most farms are relatively small, being under 66 tareas (4.125 hectares which is close to 10 acres), which reinforces the 'fractionalization' challenge that producers claimed.

The next three figures show if whether there were gains from economies of scale for the larger farms. As shown in Figure 6, the large farms are not more profitable on a per tarea basis; in fact, there is a slight decline in profitability as 
Farm Sizes

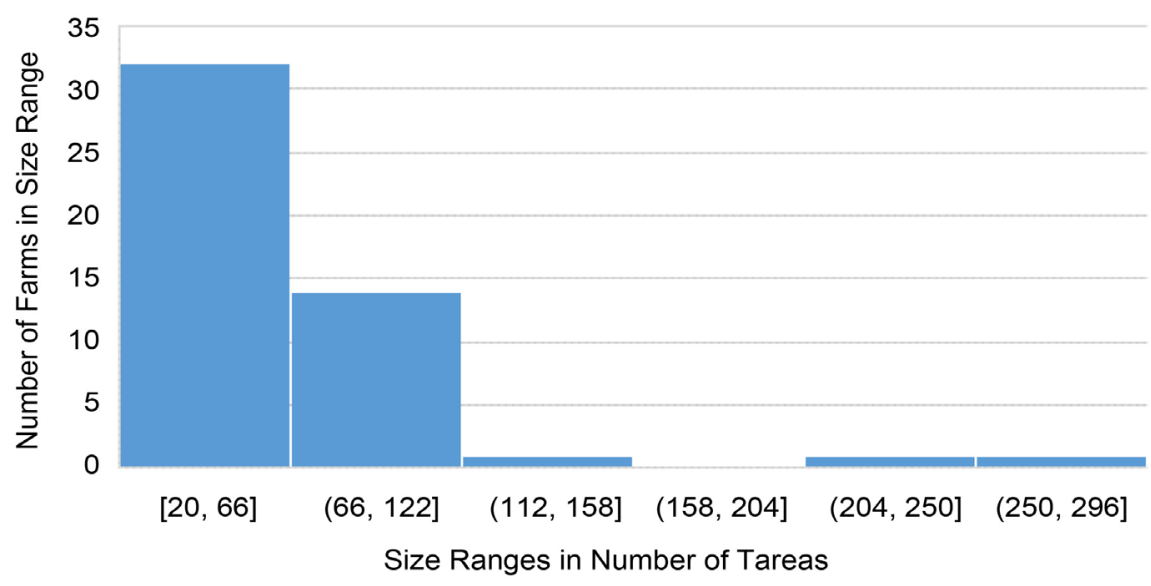

Figure 5. Farm sizes.

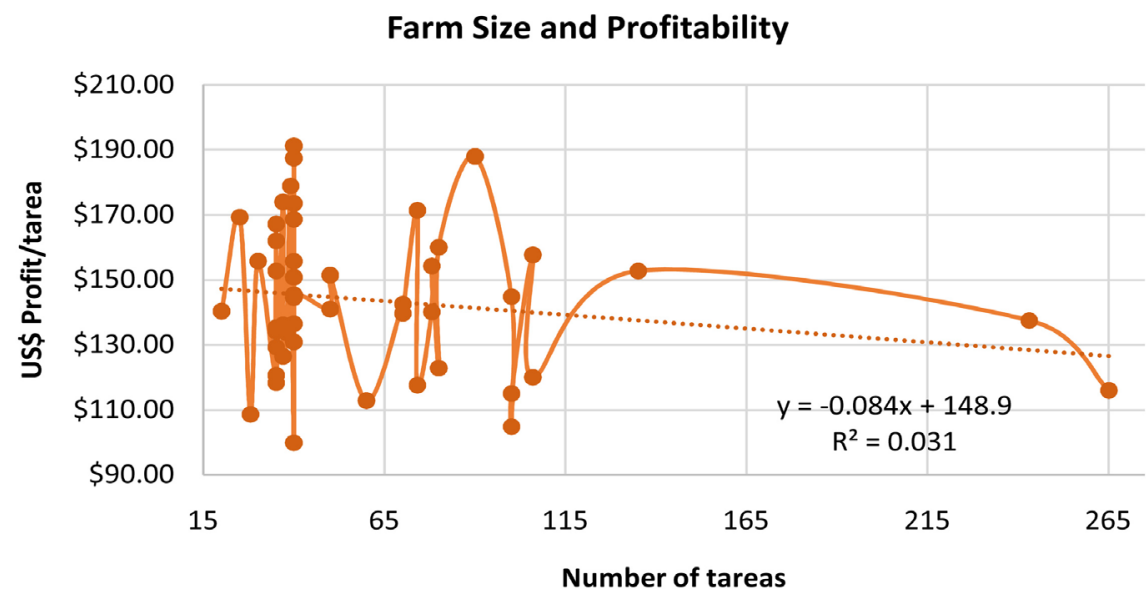

Figure 6. Farm size and profitability.

farms get larger.

The analysis applied standard cost rates to fertilizers and labor activities regardless of farm size. The variability among farms in fertilizer cost/tarea is from using different fertilizers at different rates, not from price savings due to economies of scale (Figure 7). The variability in labor costs also comes from different application rates, as some farms had certain activities, such as land preparation and irrigation activities performed more often than others (Figure 8).

After looking through the dataset it was found that standard cost rates are applied to fertilizers and labor activities regardless of size. The variability among farms in fertilizer cost/tarea is from using different fertilizers at different rates, not from price savings due to economies of scale. Variability in labor costs also comes from different application rates, as some farms had certain activities, such as land preparation and irrigation activities performed more often than others.

\subsection{Profitability}

The analysis was also used to examine profitability in relation to the various 


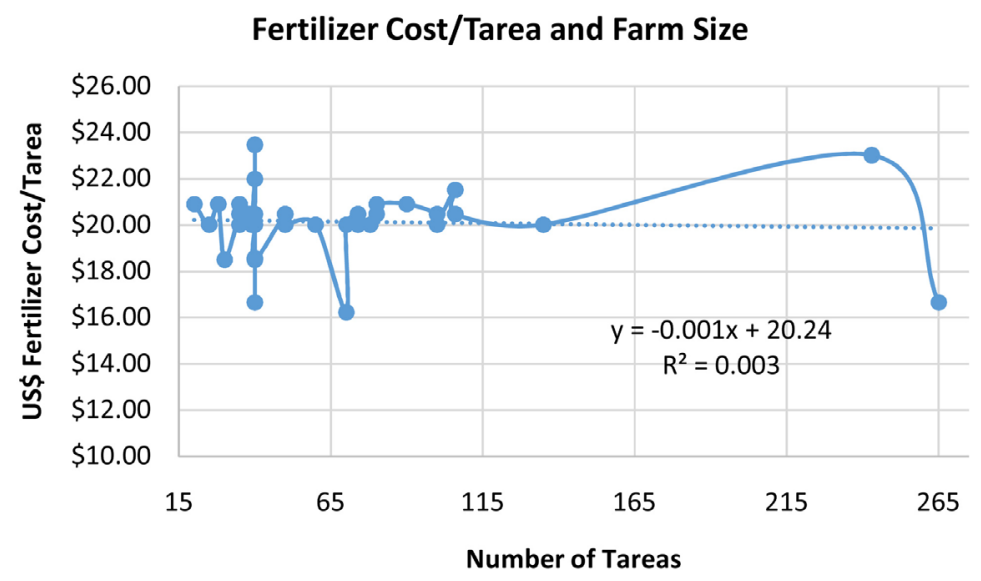

Figure 7. Fertilizer cost/tarea and farm size.

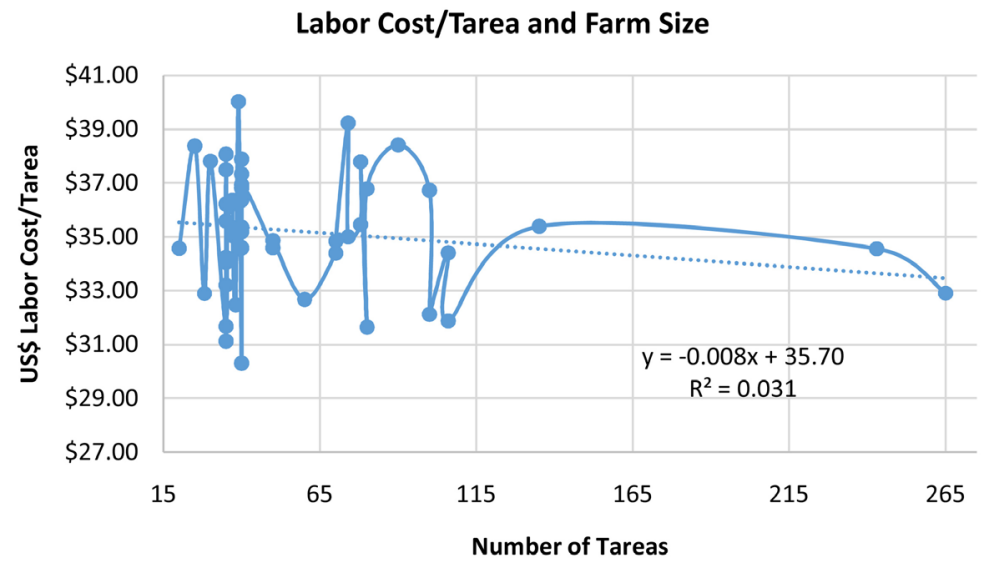

Figure 8. Labor cost/tarea and farm size.

major categories, the variable with the strongest relationship was yield. Figure 9 illustrates that yield/tarea is strongly correlated to profitability with a low degree of variance. This suggests that yield was found is a strong indicator for profitability, and investments that can be made to increase yield are sound investments.

We found that that increasing fertilizer use overall does not predict increased profitability (Figure 10). This has an implication for conservation since increasing fertilizer use does not mean profitability will increase accordingly.

The analysis for labor cost/tarea finds that there is a general, albeit fairly weak with a high degree of variance, positive relationship between labor and profitability (Figure 11). This indicates that activities other than harvesting, such as land preparation, influence profitability. Since rates for labor activities were constant in the dataset, variability comes from different amounts of labor.

From this graph it is seen that increasing fertilizer use overall does not predict increased profitability. This has an implication for conservation in that it can show to producers that increasing fertilizer use does not mean profitability will increase accordingly.

For labor cost/tarea, it was found that two subcategories of labor cost in the data set were harvesting activities that had a standard rate of US $\$ 2.77 /$ fanega, 


\section{Yield/Tarea and Profitability}

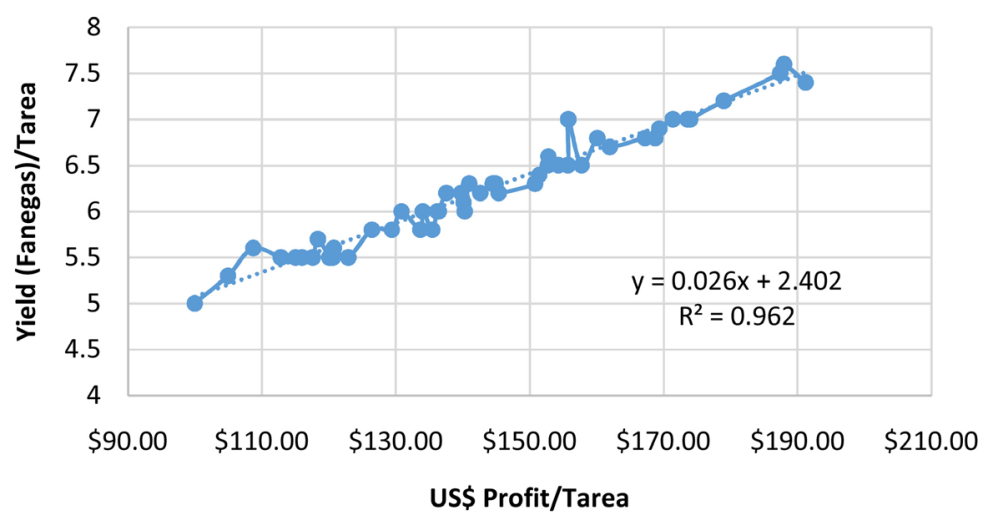

Figure 9. Yield/tarea and profitability.

Fertilizer Cost/Tarea and Profitability

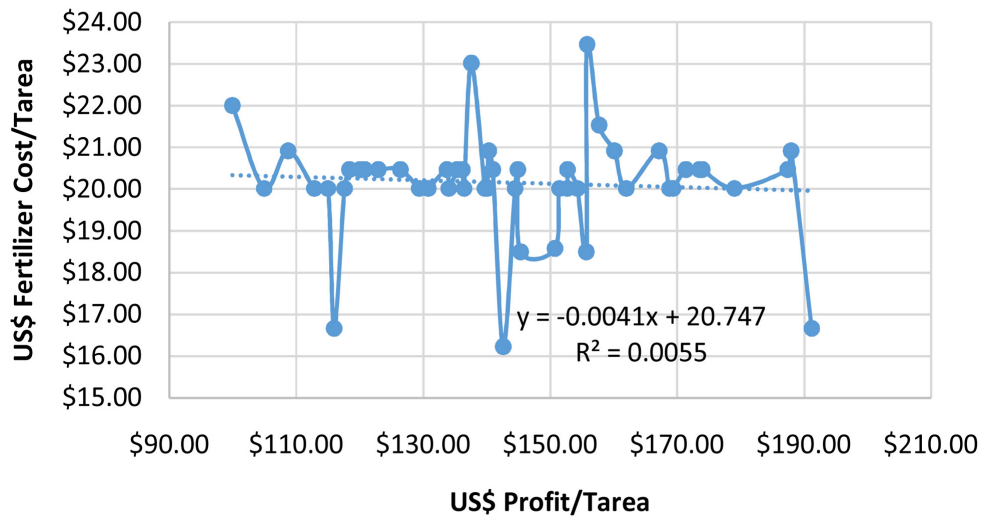

Figure 10. Fertilizer cost/tarea and profitability.

\section{Labor Cost (Not Including Harvest)/Tarea and Profitability}

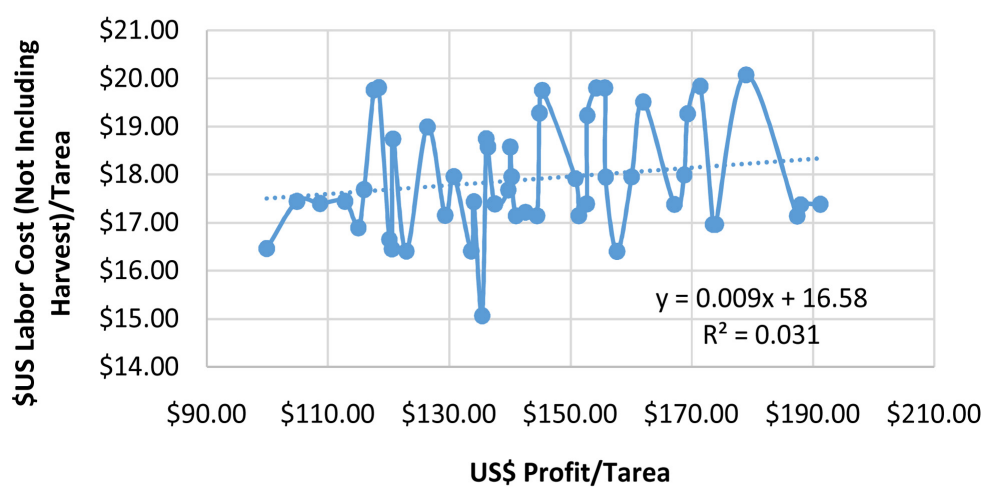

Figure 11. Labor cost/tarea and profitability.

meaning that those costs were really driven by yield itself, and would not reflect labor's relationship, independent of yield, to profitability. As can be seen there is a general, albeit fairly weak with a high degree of variance, positive relationship between labor and profitability, indicating that activities other than harvesting, 
such as land preparation, are influencing profitability.

The analysis shows that that while insecticide cost is not a major component of the overall cost, it is the main driver for the conservation efforts in Las Matas due to its effects on the area's overall ecosystem. Figure 12 illustrates that using more insecticides does not predict increased profitability.

Figure 13 illustrates that herbicide cost/tarea does not have a strong correlation to profitability and for the most part stays around US $\$ 10 /$ tarea.

Figure 14 illustrates that fungicide cost/tarea is negatively related to profitability. In looking at profitability above US\$150/tarea, there does not seem to be much return from spending more than US $\$ 2 /$ tarea on fungicide, other than two outliers at around US\$3.35/tarea.

\section{Discussion}

There seemed to be a few undercurrents among the findings, such as a lack of institutional capacity in rice production, the importance of labor in rice production, the effects of DR-CAFTA, and the role of Font Gamundi in the new sustainable rice value chain.

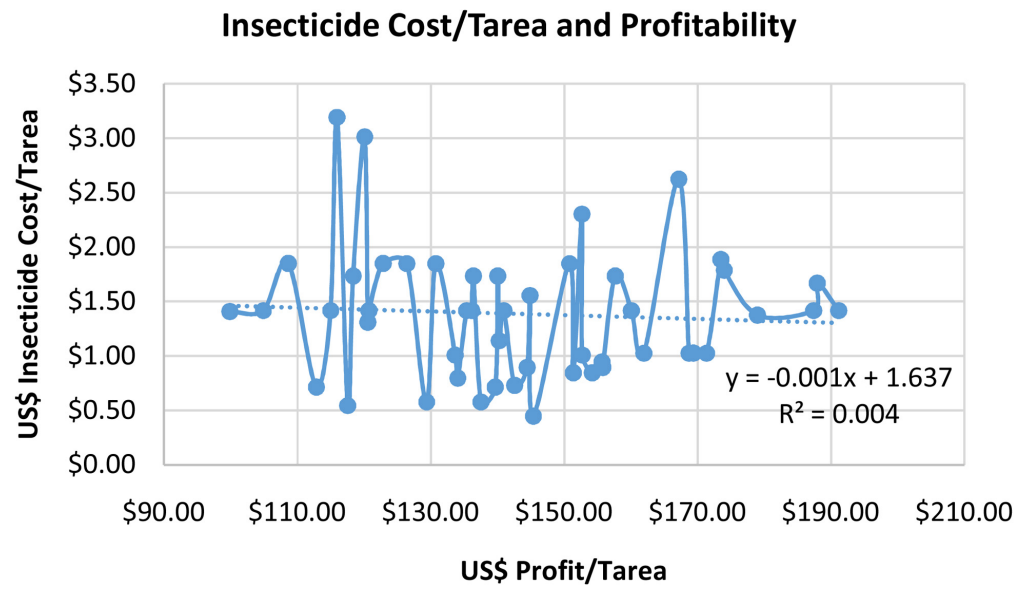

Figure 12. Insecticide cost/tarea and profitability.

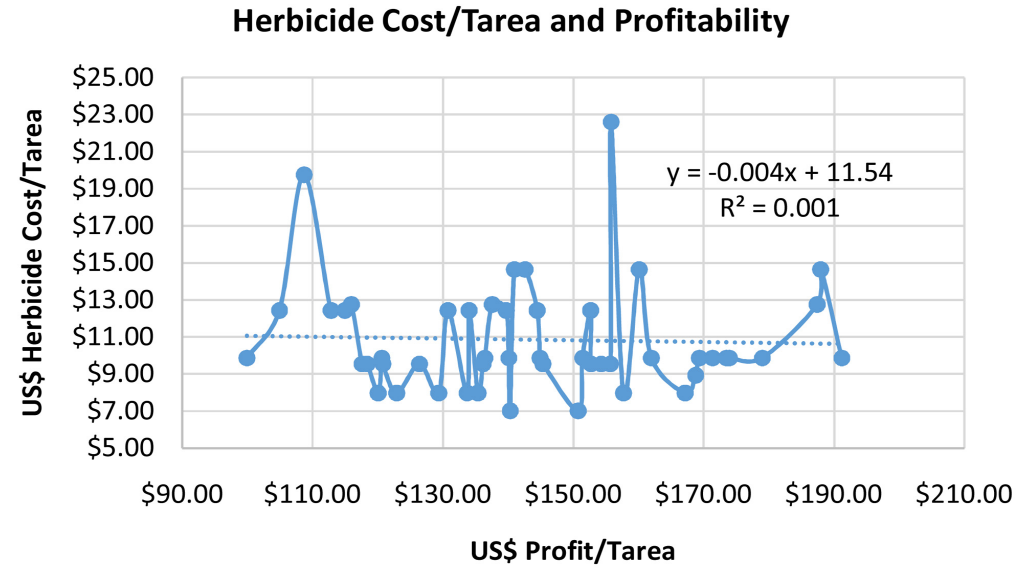

Figure 13. Herbicide cost/tarea and profitability. 


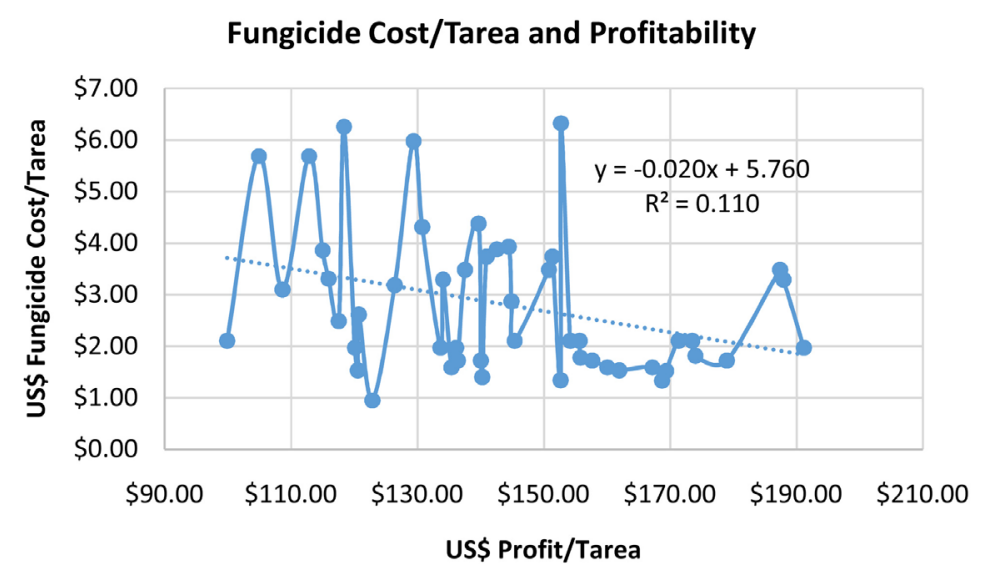

Figure 14. Fungicide cost/tarea and profitability.

It was clearly evident how the lack of organization by the rice producers in Las Matas has allowed for the unfavorable financing terms that now riddle the industry. These unfavorable terms (the conditions defined in the Debt Survey) have driven up the cost of production. And now, due to the elevated cost of production, the Dominican rice industry is threatened by US rice imports under DR-CAFTA. The lack of organization also means a lack of institutional capacity. Because most rice producers are small-plot holders and scattered, there is no voice in the industry that can dialogue with the federal government on their behalf. It seems this is a likely factor in the lack of a plan for how the rice industry, and those that make a living from it, will respond to the effects of DR-CAFTA.

Labor was shown to be important issue in both certification and profitability. First, many certifications have at least some requirements regarding worker health, safety, and/or training. Second, certifications require workers to be familiar with particular production requirements, in which case it is easier to have steady, reliable workers rather than constant rotation. Also, other than yield, labor had the strongest positive correlation to profitability from the harvest data. The trend of more labor with higher profits seems counterintuitive, but seems to indicate that certain activities, perhaps land preparation, must be done adequately to optimize yield, and additional labor to ensure these activities are done adequately therefore increases profitability. A deeper data analysis could prove or disprove this suspicion. While on the subject of human capital, the fact that no input had a very strong correlation with profitability suggests that intangibles, such as timing and tacit knowledge, have a significant impact. Also, in considering that AgroFrontera's overall goal is to create sustainable value chains, the health and wellbeing of agricultural workers must be taken into account for a value chain to be truly sustainable.

The price comparison revealed that in fact DR-CAFTA will significantly impact the Dominican rice industry. This presents a serious problem for the entire country, and the Dominican government, as many workers depend on the rice industry for their livelihood. Even if the US does not actually export great quantities to the DR, prices will surely drop. For ArroEcoZ, which could earn higher 
prices due to certification, price premiums for certified products use conventional prices as the base. Therefore, if the conventional price drops, the certified price drops as well. ArroEcoZ and AgroFrontera need to consider what will happen in Las Matasif rice cultivation becomes unprofitable and creditors look for more profitable uses of the land. The future of Las Matas as a town centered on rice production would likely change as a result. There are also implications of the DR's food sovereignty, and cultural connection to one of its food staples.

An interesting point is the role of Font Gamundi in a new sustainable rice value chain. Font Gamundi follows the effect of prices and quantities of imported US rice on the Dominican rice market, which can be useful information for ArroEcoZto become more competitive with imports. Also, in determining the appropriate certifications to pursue, Font Gamundi could help guide the evaluations of which certifications will bring the biggest returns.

Next, along the lines of competing with imported rice and the role of Font Gamundi, it would be interesting to explore how marketing could help Dominican rice growers compete with imported rice in more ways than just price. Arroz la Garza's market is still predominately in the DR, so a marketing campaign that emphasizes it as more locally grown, supporting fellow Dominicans, and grown with less chemicals could differentiate it from imported rice. Nutritional benefits, as supported by additional research, would also help differentiate Arroz la Garza.

\section{Conclusions}

An immediate conclusion to the situation is that competitiveness with US imports should be a top priority of ArroEcoZ. The price differential between current Dominican and US rice will likely have drastic effects on the Dominican rice industry. If ArroEcoZ members want to continue basing their livelihoods on rice production, they will have to be able to do so at prices much lower than the current prices.

Revamping the labor system in Las Matas could lead to increased profitability, expand capacity for certifications, and make the rice value chain in Las Matas more sustainable. Having a steady, healthy, and well-trained labor force is a gain for both employers and employees.

A broader conclusion is that farmer organizations, such as in growers associations, are vital for the viability of small-plot producers. Growers associations provide technical assistance and administrative services, facilitate access to credit, and act as an important link to the value chain. In the case of rice in NW $\mathrm{DR}$, the lack of growers associations has allowed for a production system to evolve that is ecologically, economically, and socially unsustainable.

\section{Recommendations}

First, the cost of rice production should be lowered. ArroEcoZ should set a goal that will make it competitive with US imports, keeping 2021 in mind as a time when prices will likely start falling. Setting this goal can be facilitated with in- 
formation from Font Gamundi. Lowering the cost of production can be accomplished by a process of investments, starting with bulk purchasing programs and coordinating machine services, and then by investing in technologies such as transplanters. Transplanters would allow for the SRI system to be adopted without significant increases in labor costs.

Second, ArroEcoZ should begin to formalize the labor system for members' rice production. The process could begin with identifying the aggregate labor needs of ArroEcoZ members and recruiting workers who would be dedicated to working for ArroEcoZ members.

Third, ArroEcoZ should act as an intermediary for member financing, rather than directly provide financing by dividing up a bulk loan. This would reduce the administrative burden on ArroEcoZ, and also would deter potential corruption issues in the future by not having large amounts of funds on the books.

Fourth, ArroEcoZ should maintain some type of leverage in their relationship with Font Gamundi. Font Gamundi is a partner and an ally in competing with imports; however, having only one buyer reduces a supplier's negotiating power. ArroEcoZ will have to find ways to balance maintaining their relationship with Font Gamundi while still having leverage to ensure terms do not become unfavorable.

Lastly, as a more broad recommendation, all grower associations need to have a structure, as in bylaws and procedures, that facilitates transparency, and mitigates corruption and infighting. This is an area for follow up research that has great implications for agricultural development projects in the developing world. A succinct way to illustrate this point is that agriculture involves people, and therefore understanding people is vital.

\section{Conflicts of Interest}

The authors declare no conflicts of interest regarding the publication of this paper.

\section{References}

[1] Mayol, V. and Perkins, M. (2016) Dominican Republic: Grain and Feed Annual 2016. USDA Foreign Agricultural Service, Washington DC.

[2] Convention on Biodiversity (2016) Dominican Republic-Country Profile. https://www.cbd.int/countries/profile/default.shtml?country=do

[3] World Atlas (2018) Dominican Republic. https://www.worldatlas.com/webimage/countrys/namerica/caribb/do.htm

[4] Ferguson, J. (1992) The Dominican Republic: Beyond the Lighthouse. LAB, London.

[5] Central Intelligence Agency (CIA) (2016) World Fact Book: Central America and Caribbean: Dominican Republic. https://www.cia.gov/library/publications/the-world-factbook/geos/dr.html

[6] World Bank (2016) Dominican Republic Overview. http://www.worldbank.org/en/country/dominicanrepublic/overview 
[7] Lamm, S. (2016) Poverty in the Dominican Republic. http://www.worldbank.org/en/country/dominicanrepublic/overview

[8] United Nations Development Program (UNDP) (2016) Table 2: Trends in Human Development Index 1990-2014. http://hdr.undp.org/en/composite/trends

[9] Central Intelligence Agency (CIA) (2016) Country Comparison: Distribution of Family Income-Gini Index.

https://www.cia.gov/library/publications/the-world-factbook/rankorder/2172rank.h $\underline{\mathrm{tml}}$

[10] World Bank (2016) Health Expenditure (\% GDP). http://data.worldbank.org/indicator/SH.XPD.PUBL.ZS?name_desc=true

[11] Educational Data Policy Center (EDPC) (2016) Dominican Republic: National Education Profile Update 2014.

http://www.epdc.org/sites/default/files/documents/EPDC\%20NEP_Dominican\%20 Republic.pdf

[12] Reyes, J., et al. (2017) Special Economic Zones in the Dominican Republic: Policy Considerations for a More Competitive and Inclusive Sector. World Bank, Washington DC.

[13] Marte, W., Nanseki, T. and Takeuchi, S. (2011) Towards Farm Management Strategies on Dominican Rice Farming under DR-CAFTA: A Case Study of Monte Cristi Province. Journal of the Faculty of Agriculture Kyushu University, 57, 265-272.

[14] Instituto Dominicano de Investigaciones Agropecuarias y Forestales (IDIAF) (2010) Dictan Conferencia Sobre los Efectos del DR-CAFTA en el Sector Arrocero Dominicano. http://www.idiaf.gov.do/noticias/detallemain.php?ID=1096

[15] Food and Agriculture Organization of the United Nations (FAO) (2018) Organic Banana Production in the Dominican Republic.

http://www.fao.org/world-banana-forum/projects/good-practices/organic-producti on-dominican-republic/en/\#.XBb6Vs9KiCQ

[16] Metz, R. (2017) El Municipio de Las Matas de Santa Cruz, Montecristi.

https://montecristialdia.blogspot.com/2013/10/el-municipio-de-las-matas-de-santacruz.html

[17] Oficina Nacional de Estadística (ONE) (2008) Monte Cristi en Cifras: Perfil Sociodemográfico Provincial. https://www.one.gob.do/

[18] AgroFrontera (2016) Sustainable Rice Production in the Northwest Dominican Republic: Creating Innovations in Rice Value Chains.

http://www.agrofrontera.org/quienes-somos.html

[19] Maltchik, L., Stenert, C. and Batzer, D. (2017) Perspectives: Can Rice Field Management Practices Contribute to the Conservation of Species from Natural Wetlands? Lessons from Brazil. Basic and Applied Ecology, 18, 50-56.

https://doi.org/10.1016/j.baae.2016.10.002

[20] Quintal, O., Ramadass, P. and Santhi, V. (2007) Organic Rice Production: A Case Study in Tamil Nadu, India. Pesticide Action Network Asia and the Pacific (PANAP), Penang.

[21] SRI-Rice (2016) SRI Methodologies. http://sri.cals.cornell.edu/aboutsri/methods/index.html

[22] Jouzi, Z., et al. (2017) Organic Farming and Small-Scale Farmers: Main Opportunities and Challenges. Ecological Economics, 132, 144-154.

https://EconPapers.repec.org/RePEc:eee:ecolec:v:132:y:2017:i:c:p:144-154 https://doi.org/10.1016/j.ecolecon.2016.10.016 
[23] Ara, S. (2002) Environmental Evaluation of Organic Rice: A Case Study in the Philippines. M.S. Thesis, Kobe University, Kobe.

[24] Kristiansen, P., Taji, A. and Reganold, J. (2006) Organic Agriculture: A Global Perspective. CSIRO Publishing, Collingwood. https://doi.org/10.1079/9781845931698.0000

[25] International Federation of Organic Agriculture Movements (2017) Internal Control Systems (ICS) for Group Certification. http://www.ifoam.bio/en/internal-control-systems-ics-group-certification

[26] USDA-FAS (2018) Global Agricultural Trade System (GATS). https://apps.fas.usda.gov/gats/ 


\section{Appendix A}

Glossary of Terms.

Gini Coefficient-A measurement of wealth distribution in a society, commonly used to measure inequality, whereby the higher the Gini Coefficient, the more unequal a society is.

GDP-Gross Domestic Product. The summed value of all products and services produced in one country in a year.

Fanega-100 kilogram sack of unprocessed rice, still in hull. Used as the standard unit of measure of rice yields in Dominican Republic.

NGO-Non-Governmental Organization. A not-for-profit organization that works to bring about change for particular causes.

NW-Northwest

Tarea-628 square meters. Used as a standard unit of measure of land in the Dominican Republic.

\$RD-Dominican peso.

USDA-United States Department of Agriculture.

\section{Appendix B}

Organizations Involved in Project.

\begin{tabular}{|c|c|c|}
\hline NAME & DESCRIPION & ROLE IN PROJECT \\
\hline AgroFrontera & $\begin{array}{l}\text { Dominican NGO based in NW DR that } \\
\text { works with fishermen and } \\
\text { farmers to create sustainable value chains }\end{array}$ & Host Institution \\
\hline ArroEcoZ & $\begin{array}{l}\text { Rice growers association in } \\
\text { Las Matas de Santa Cruz }\end{array}$ & Primary Beneficiaries \\
\hline BANAMIEL & $\begin{array}{c}\text { Banana growers } \\
\text { association in NW DR }\end{array}$ & $\begin{array}{l}\text { Interviewed about rise of the } \\
\text { DR organic banana industry }\end{array}$ \\
\hline BANELINO & $\begin{array}{c}\text { Banana growers } \\
\text { association in NW DR }\end{array}$ & $\begin{array}{l}\text { Primary institution for Phase } \\
\text { 2. Interviewed about rise of } \\
\text { the DR organic banana } \\
\text { industry, their operations, } \\
\text { and facilitated interviews } \\
\text { with } 7 \text { members that were } \\
\text { certified organic growers. }\end{array}$ \\
\hline COOPBANDO & $\begin{array}{c}\text { Banana growers } \\
\text { association in NW DR }\end{array}$ & $\begin{array}{l}\text { Interviewed about rise of the } \\
\text { DR organic banana industry }\end{array}$ \\
\hline $\begin{array}{c}\text { Florida } \\
\text { Organic Growers }\end{array}$ & $\begin{array}{l}\text { Florida-based NGO that conducts } \\
\text { education and outreach, and } \\
\text { certification services for certified } \\
\text { organic growers in Florida }\end{array}$ & $\begin{array}{l}\text { Introduced research } \\
\text { team to AgroFrontera }\end{array}$ \\
\hline Lan Fruits & $\begin{array}{c}\text { Exporter of organic bananas } \\
\text { based in NW DR }\end{array}$ & $\begin{array}{c}\text { Interviewed about rise of the } \\
\text { DR organic banana industry } \\
\text { and keys to grower } \\
\text { association success in the DR }\end{array}$ \\
\hline $\begin{array}{l}\text { Quality Certifica- } \\
\text { tion Services }\end{array}$ & $\begin{array}{l}\text { Certifying agency of various } \\
\text { agricultural certifications in DR }\end{array}$ & $\begin{array}{l}\text { Interviewed about rise of the } \\
\text { DR organic banana industry } \\
\text { and challenges producers face } \\
\text { in becoming certified organic }\end{array}$ \\
\hline
\end{tabular}




\section{Appendix C}

Initial Meeting with AgroFrontera Staff.

- Introduction to rice production in Montecristi

- Current varieties of rice being grown

- Current use of prohibited items per the QCS list. List products currently in use. Assign ballpark figures on how much each is currently being used.

- Current production issues in Montecristi-pests, irrigation, fertility, marketing, etc.?

- Yield performance v. yield potential

- Community knowledge on organic rice production

- Value Chain Analysis

- Capacity of farmer association/organizations. How strong are the organizations and what role do they have in the community?

- Go over QCS checklist and field plan to identify biggest challenges to conversion

\section{Appendix D}

Initial Meeting with Rice Distributors.

- What price do you generally pay for the Dominican rice?

- What is your selling price for rice?

- Do you sell to retail markets?

- What are the consumer preferences?

- Do you have any experience/knowledge with organic products?

- Do you think there could be local/national demand for organic rice?

- Do you know of any DR-CAFTA counter strategies?

- Who distributes imported rice?

- Do you know the price of US imported rice?

- If not, do you have any projection?

- Is there imported rice from anywhere else beside the United States?

- What effects do you think the imported rice will have on Dominican rice growers?

\section{Appendix E}

Initial Meeting with QCS Staff.

- What are the major/most common/most difficult to cut out substances for growers?

- Are there organic substitutes for prohibited items?

- Which production practices changed during/after conversion?

- What are the administrative requirements of farmers?

- How would you describe the overview of Dominican organic industry-regulatory framework, technical issues, export requirements, etc.?

- What is your organization's story on how the organic banana industry grew? 
- Is there possibility for an Internal Control System?

\section{Appendix F}

Interviews with Certified Banana Farms.

- What was your experience in becoming a certified organic farm?

- What motivated you to become certified organic?

- What were the major obstacles to becoming a certified organic farm?

- How did you overcome those obstacles?

- Has becoming certified organic improved your financial situation?

- In general, how was your experience during the conversion process?

- Have you seen many changes in how your farm operates during conversion and after certification?

- What kind of practices did you have to adopt/change for fertility, pest, and weed management?

- Would you do anything differently about your conversion if you could do it over again?

\section{Appendix G}

Meeting with Current Organic Dealers.

- What is the current state of the market for Dominican organic products?

- Do you have any projections for how Dominican organic products will do over the next few years?

- Can you tell me about consumer preferences for organic products?

- Do you think there is a potential market for organic Dominican rice?

- If so, which market do you think is best?

- Were there any barriers to establishing an organic industry in the Dominican Republic?

- How did distributors overcome the barriers?

- What do you think was the key for the Dominican organic industry becoming so successful?

\section{Appendix H}

Debt Survey.

- Que tipo de financiamiento usa Ud.?

(What type of financing do you use?)

- PrivadoIndependiente/Privado de Agroquímica/Financiador/Banco Agrícola/Cooperativa/Banco/Auto-financiado

(Private Independent/Private AgroChemical/Financier/BancoAgrícola/

Cooperative/Bank/Self-financed)

- Su fuente de financiamientopermite a Ud. prestar efectivo para compra de insumosagrícolas en vez de cargarlo?

(Does your source of financing allow you to borrow cash in order to buy agricultural inputs instead of charging them to credit?) 
- Su fuente de financiamientopermite a Ud. buscar para suspropiosinsumos?

- (Does your source of financing allow you to search for your own inputs?)

- Su financiador le permite a Ud. vender su arroz? (Does your source of financing allow you to sell your rice?)

- Tiene Ud.deuda con su fuente de financiamientoanterior? ${ }^{*} \mathrm{Si}$ Ud. contesta "No" a esta pregunta, yacumplió la encuesta.

(Do you have previous outstanding debt with your source of financing? ${ }^{\star}$ If you answer "No" to this question, you have finished the survey.)

- Si escierto, cuanto?

(If yes, how much?)

- Cual es su garantía de pago?

(What is the guarantee for payment [collateral]?)

\section{Appendix I}

Debt Survey Results.

1) What type of financing do you use?

- Private Independent-8\%

- Private Agrochemical-48\%

- Financier-6\%

- BancoAgrícola-18\%

- Cooperative-6\%

- Bank-0\%

- Self-financed-14\%

2) Does your source of financing allow you to borrow cash in order to buy agricultural inputs instead of charging them to credit?

Yes-50\%

No-50\%

${ }^{\star}$ Of those using Private Agrochemical financing:

Yes- $17 \%$

No- $83 \%$

3) Does your source of financing allow you to search for your own inputs?

Yes-52\%

No- $48 \%$

${ }^{*}$ Of those using Private Agrochemical financing:

Yes-21\%

No-79\%

4) Does your source of financing allow you to sell your rice?

Yes-70\%

No-30\%

${ }^{\star}$ Of those using Private Agrochemical financing:

Yes- $46 \%$

No-54\%

5) Do you have previous outstanding debt with your source of financing? 
*If you answer "No" to this question, you have finished the survey. Only 3 answered "Yes" to this question.

6) If yes, how much?

In USD: $\$ 14,862 ; \$ 10,616 ; \$ 16,985$

7) What is the guarantee for payment (colateral)?

All three answered "la parcela"; their parcel itself. 